\title{
Osmanlı Dönemi Kıbrıs Su Vakıfları (1571-1878)
}

\author{
Cyprus Water Waqfs of the Ottoman Period (1571-1878)
}

\section{Güven DİNÇ* Cemil ÇELİK*}

Özet: Vakıf kelimesi durdurmak, alıkoymak anlamlarına gelmekte ve İslâm hukukunda bir sistemi ifade etmektedir. Vakıf bir kişinin, sahip bulunduğu taşınır veya taşınmazın bir kısmını veya tamamını halkın herhangi bir ihtiyacını gidermek üzere Allah rızası için, hayrî ve sosyal bir amaca devamlı surette tahsis etmesi demektir. Vakıfların çeşitlerini toplumların ihtiyaçları belirlemektedir. Kıbrıs Adası yarı kurak iklim kuşağında yer aldığından ve yerel su kaynakları da kısıtlı bulunduğundan adada kurulan vakıfların önemli bir kısmı su vakfı şeklinde olmuştur. Adada ilk vakıf kuranlar Padişah II. Selim, Lala Mustafa Paşa, Haydar Paşazade Mehmet Bey, Arap Ahmet Paşa, Pertev Paşa, Ağa Cafer Paşa gibi devlet erkânından hayırseverlerdi. Cafer Paşa, Ebubekir Paşa, Silahtar Mustafa Paşa gibi valiler, ada halkına sadece adaletli bir idare sunmaya çalışmamışlar, aynı zamanda halkın en önemli ihtiyacını kendi gelirlerinden kurdukları su vakıflarıyla karşılamaya gayret etmişlerdir. Ayrıca ada halkından varlıklı olanlar da mevcut su vakıflarının devamını sağlamak üzere bağışlar yapmışlardır. Bazıları da vakıf su yollarını kullanmak üzere yardımlarda bulunmuşlardır. Ayrıca Kıbrıs su vakıflarının ülkenin diğer su vakıflarıyla büyük benzerlikler taşıdığı da ortaya çıkarılmıştır. Bu çalışmanın amacı, Osmanlı Dönemi’nde Kıbrıs'ta suya verilen önemi, adaya atanan yöneticilerin Kıbrıs halkının su ihtiyacını karşılamadaki gayretlerini değerlendirmek, adada kurulan su vakıflarının kimler tarafından oluşturulduğunu, var olanlara su vakıflarına yapılan destekler ile vakıflardan meydana gelen gelişmeleri ortaya çıkarmaktır. Böylece Kıbrıs vakıflar tarihi içerisinde su vakıfları konusundaki eksikliğin giderilmesine katkı yapılması hedeflenmektedir.

Anahtar sözcükler: Kıbrıs, vakıf, su, su vakıfları, su yolu, Lefkoşa.

Abstract: Literally, the waqf words means to stop, contain or to preserve and it is a system in Islamic law. In shari'ah, a waqf is a voluntary, permanent, irrevocable dedication of a portion of ones wealth - in cash or kind - to Allah. Needs of communities determine the type of waqf. Cyprus is located in semi-arid climatic zone. In addition to this, water resources are limited in the island. Therefore, in Cyprus a large number of water vaqfs were established. The first founders of the waqf in the island were benefactor of high state official, such as Sultan Selim II, Lala Mustafa Pasha, Haydar Pashazade Mehmet Bey, Arap Ahmet Pasha, Pertev Pasha, Ağa Jafar Pasha. Not only fairly admisitrated the governer of the island such as Jafar Pasha, Abu Bakr Pasha, Mustafa Pasha but also endeavored to supply the water needs of the people, by establishing water waqf. Besides, wealthy people of the island made donations to maintain the existing the water waqfs. Some of them made contribute to the waqf for using the waterways. It is also revealed that Cyprus water waqfs resembles other water waqfs in the country. The aims of this study are; to evaluate the importance of the water in Cyprus during the Ottoman period and the efforts of governers of Cyprus related to the water; to reveal the founders of the water waqfs and supporters the water waqfs existing in the island, and the events of the water waqfs. In addition to this, to complete deficiency of the matter of water waqfs within the history of the Cyprus waqfs is aimed.

Keywords: Cyprus, waqf, water, water waqfs, waterways, Nicosia.

\footnotetext{
*Yrd. Doç. Dr., Akdeniz Üniversitesi, Edebiyat Fakültesi, Tarih Bölümü, Antalya, gdinc@akdeniz.edu.tr

** Doktora, Akdeniz Üniversitesi, Edebiyat Fakültesi, Tarih Bölümü, Antalya, cemilcelik736@yahoo.com.tr
} 


\section{Giriş}

Kelime olarak "durdurmak", "alıkoymak" anlamlarına gelen vakıf terimi, İslâm hukukunda bir sistemi ifade etmektedir. Bu anlamda bir kişinin, mülkiyetine sahip bulunduğu menkul veya gayrimenkulün bir kısmını veya tamamını Allah rızasını kazanma niyetiyle, halkın herhangi bir ihtiyacını gidermek üzere dinî, hayrî ve sosyal bir amaca müebbeden tahsis etmesi demektir (Yediy1ld1z, 1986, 153; 1999, 2).

Türk-İslâm tarihinin sosyal, kültürel ve ekonomik hayatında büyük rol oynamış dinî ve hukukî boyutları bulunan vakıf sistemi, eski medeniyetlerde farklı isimlerle ve uygulamalarla görülmekle beraber (Akgündüz, 1988, 11-14) Osmanlı İmparatorluğu'nda uygulandığı biçimiyle ilk kez İslâmiyet'le ortaya çıkmış, Peygamber'in hadisleriyle şekillenmiştir (Öztürk, 1983, 45; Kazıc1, 1985, 48; Akgündüz, 1988, 15).

İslâm tarihinde sularla ilgili kurulan vakıflar Hz. Peygamber döneminde başlamıştır. Hz. Osman, hicretten sonra başta Medine halkının su ihtiyacını gidermek amacıyla yüksek bir meblağla Rume Kuyusu'nu satın alarak vakfetmişti. Peygamber'in övgüsüne mazhar olan bu davranış daha sonraki dönemlerde de pek çok Müslüman tarafindan örnek alınmış ve su hizmetlerine yönelik vakıfların tesis edilmesinde teşvik edici unsur olmuştur (Karataş, 2008, 387).

Kendinden önceki Türk-İslâm devletlerinin mirasını devralarak bunları bir tekâmüle erdiren Osmanlı medeniyeti vakıf konusunda oldukça gelişmiştir (Köprülü, 1942, 13; Berki, 1962, 127 128). Osmanlı medeniyetinin bu alandaki en önemli faaliyet alanlarından biri de su vakıflarıdır. Nitekim Osmanlı İmparatorluğu'nun kuruluşuyla birlikte su vakıfları tesis edilmeye başlanmıştır. Hemen her padişah, inşa ettiği külliye için su getirtmiş, bu sularla ilgili hizmetlerin aksamaması için de vakıflar kurmuşlardır. İlk başkent olan Bursa'daki padişah külliyelerine getirilen sular için de vakıflar vardır. Bu uygulama daha sonraki dönemlerde de devam etmiştir. Kanuni Sultan Süleyman'ın su vakıfları bunlar arasında en meşhurlardandır (Ateş, 1987, 9 vd.).

Daha önce Kıbrıs evkaf tarihi üzerine müstakil çalışmalar yapılmıştır. B. Remzi Özoran (1982), M. H. Altan (1986, 2001), M. Â. Erdoğru (2009), M. Demiryürek (2011), A. Kara ve C. Çelik (Kara ve Çelik, 2011) bu alanda incelemeler ortaya koymuşlardır. Bunlardan Altan, kapsamlı çalışmalarında Kıbrıs'ta tespit edebildiği bütün vakıfları bulabildiği vakfiye kayıtlarıyla birlikte kayda almış; Özoran, Bekir Paşa vakfını; Erdoğru, 1572 tarihli mufassal defterden yola çıkarak adada açılan ilk Osmanlı vakfinı; Demiryürek, Kıbrıs şer'iyye sicilleri temelinde XVIII. yüzyılın ilk yarısında adada kurulan para vakıflarını konu edinmiş; Kara ve Çelik ise İngiliz idaresi başlangıcında Kıbrıs vakıflarının yönetiminde karşılaşılan sorunları irdelemişlerdir. Kıbrıs evkafı üzerine bu müstakil çalışmalardan ayrıca Jennings (1993) N. Çevikel (2000), A. Gazioğlu (2000), A. E. Özkul (2005), C. Erdönmez (2004), T. Bağışkan (2005), H. Çoruh (2008) da çalışmalarının kapsamına giren ölçüde Kıbrıs vakıfları üzerinde durmuşlardır. Bunlardan Jennings, adada kurulan ilk Osmanlı vakıflarına ilişkin bilgiler verirken, Bağışkan, vakıf olup olmadığını ayırt etmeksizin adada tespit edebildiği bütün Osmanlı eserlerini kayıtlara geçirmiş ve kısaca tanıtmıştır. Gazioğlu ise genel anlamda Osmanlı Dönemi Kıbrıs vakıflarını, çalışmasının kapsamına göre sathi biçimde ele alırken konumuzla ilintili olan su vakıflarına ayrı bir vurgu yapmıştır. Ayrıca N. Yıldız'ın (1986) incelemesi de çalışmamıza 1şık tutmuştur. Ancak şu ana kadar Osmanlı Dönemi'nde Kıbrıs su vakıflarını müstakil biçimde inceleyen bir çalışma bulunmamaktadır.

Bu çalışmada 1570 yılında Kıbrıs Adası'nın fethinden 1878'e dek kurulan su vakıfları konu edilmektedir. Böylece Kıbrıs'ta suyun değeri bir kez daha gözler önüne serilirken, aynı zamanda su alanında hangi vakıfların kurulduğu, işleyişleri ve belki de günümüzde kaybolmuş eski su kaynakları ortaya çıkarılabilecektir. Böylece Kıbrıs vakıflar tarihine katkı yapılması amaçlanmaktadir. 
Su vakfi anlamında belirtilmesi gereken husus, incelemede cami, tekke vb. başka vakıfların giderlerine vakfedilen sulardan elde edilen gelirler değerlendirmeye tabi tutulmamıştır. Kıbrıs'ta kişilerin tasarruflarında tuttukları su haklarını, vakıfların mutad giderlerini (örn. tevliyet, mevlid-i şerif okumak, hatim indirmek, mum giderleri vb.) karşılamak üzere vakfedilmesi yaygın bir uygulamadır. Ancak bu husus Kıbrıs halkının su ihtiyacını karşılamaya yönelik olmadığından sadece halkın su ihtiyacına binaen vakfedilen sular veya var olan suları geliştirmeye yönelik vakıflar incelemeye tabi tutulmuştur.

Çalışmada öncelikle, vakıfların çeşitlerini toplumların ihtiyaçları belirlediğinden Kıbrıs'ta suyun önemine vurgu yapılmış, ardından adada ilk su vakıflarının ne zaman kurulduğu konu edilmiştir. Kıbrıs'ta oluşturulan büyük su vakıfları ise ayrı başlıklar altında değerlendirilmiştir. Kıbrıslıların su vakıflarına katkıları, su vakıfları konusunda yaşanan sorunlar, ortak çalışmalar ele alınan diğer konulardır. Kaynak olarak Kıbrıs Şer‘iyye Sicilleri temel alınmıştır.

\section{Kıbrıs'ta Suyun Önemi}

$\mathrm{Su}$ insan yaşamının temelini oluşturan hava, ateş, toprak gibi "anâsır-ı erbaa"dan biridir ve vazgeçilmez bir ihtiyaçtır. Bu sebeple yerleşim yerleri, çağlar boyunca su kaynaklarına yakın bölgelerde kurulmuş ve büyük medeniyetler de suyun yeşerttiği coğrafyalarda doğmuştur.

Kıbrıs Adası, makro iklim sınıflandırılmasına göre "yarı kurak" şeklinde adlandırılan iklim kuşağında yer aldığından ve aynı zamanda Akdeniz iklim alanında bulunduğundan yazları sıcak ve kurak, kışları 1lık ve yağışlı geçer. Yağmurlar daha çok Kasım-Nisan döneminde yoğunlaşmaktadır. Yazların kurak geçmesi bahçe tarımı ve hayvancılığın verimli ve sulanabilir küçük vadilerle sınırlı kalmasına yol açmıştır.

Kıbrıs'ın eski dönemlerde gereksinim duyulan su ihtiyacı pınarlar, kuyular ve sarnıçlara doldurulan yağmur sularından sağlanırken, ilk kez Roma Dönemi'nden itibaren arıklar ve kemerlerle başka yerlerden su taşıma çalışmalarına başlanmıştır. Değirmenlik'ten Salamis'e 23 $\mathrm{km}$. uzunluğunda oluşturulan su kemerleri bu dönemin en önemli eserleri arasında gösterilmektedir (Hill, 1952a, 6, 253, 280).

XVI. yüzyılda Piri Reis, Kıbrıs haritasında üç ırmak çizmiştir. Bunların ilki Girne Kalesi'nin doğusundan akan kısa ırmak, ikincisi Lefkoşa'nın güneyindeki dağlardan doğup güneye yönelen ve Leymosun'un doğusundan denize dökülen ırmak, üçüncüsü ise adanın güneyinde Akyurt denilen yerden, olasılıkla Piskopu civarından denize dökülen uzun nehirdir (Erdoğru, 2008, 224).

Osmanlı yönetiminin başlarında Lefkoşa, Girne ve Karpas kazalarında 42 değirmen bulunmaktaydı. Bunlar ve Venedik yönetiminde kullanılan su kaynakları ile örfî ve hukukî uygulamalar pragmatist biçimde fazla değiştirmeden sürdürüldü (Erdoğru, 2008, 250, 265-266). Bunun yanında Venedik ve eski devirlerden itibaren kullanılan, ancak yıpranan ve bozulan su sistemlerinin ıslah çalışmaları gerçekleştirildi. Kıbrıs'ın Osmanlı yönetimindeki ilk bütçe defterinde Lefkoşa'ya su getiren kemerlerin inşaatına 25.800 akçe para harcandığı görülmektedir (Sahillioğlu, 1967, 17). 1576 tarihli bir başka belgede ise yeterli suyu olmayan Girne Kalesi'ndeki suyun açık hendeklerde akması nedeniyle temiz olmadığı dile getirilmiş, ayrıca suyu arıtabilecek kemerler inşa etmek üzere gerekli paranın devlet hazinesinden karşılanması istenilmişti (Yıldız, 1996, 93; Bağışkan, 2005, 393-394).

Kıbrıs'ta, Osmanlı Dönemi'nde sulanması mümkün olmayan arazilerde tarım, sadece açılan su kuyularıyla yapılabiliyordu. Bu yüzden tarlalar Kıbrıs'ta değerlerine ve özeliklerine göre kıraç, sulu, su basar ve âlâ tarlalar şeklinde gruplandırılmaktaydı. Akarsularla sulanabilir araziler Kıbrıs topraklarında Mesarya, Karpas, Leymosun ve Hirsofi kazalarında yoğunlaşmaktaydı. Ekilebilen araziler için yeterli su kaynakları bulunmadığından, akarsu veya su kuyularına sahip olanlar suları satarak veya kiralayarak büyük gelirler sağlayabiliyordu. Yani su haklarından belirli sürelerle kazanç elde edilebiliyordu. Bu değerler, şahısların tasarruflarında bulunan da- 
kika, saat, gün ve hafta olarak gösterilen su tasarruf haklarından belirlenen miktarlardı. XIX. yüzyılda temattüat sayımlarında da bu haklar bir değer olarak kayıtlara geçirilmiştir. Sözgelimi Girne Kazası'nın 1.532.081 kuruşluk toplam kıymeti içerisinde su, 72.326,5 kuruşla \% 4,7'lik bir orana sahipti (Özçelik, 2003, 61). Ayrıca şer'iyye sicilleri, bu hakların satışıyla, devriyle veya yaşanan sorunlarla ilgili çok sayıda hüküm barındırmaktadır.

\section{Kıbrıs'ın İlk Su Vâkıfları}

Kıbrıs Adası'nın 1570'te Osmanlı egemenliğine alınması ve akabinde Anadolu'dan Türk-İslâm ahalinin yerleştirilmesiyle Kıbrıs klâsik bir Osmanlı toprağı hüviyetini kazandı (BOA., A.DVN. MHM.d, 19, s. 334-337, hük.1, H. 19 Ağustos 1572/ M. 9 Rebiülâhir 980; Dündar, 1998, 331 vd.). Böylece adada vakıf sistemi de oluşmaya başladı. Zirâ Anadolu'dan gelen halk, sadece fizikî bir varlık değil, aynı zamanda bir kültür ve medeniyet aktarımı vazifesini de üstlenmişti. Dolayısıyla fetihten hemen sonra adada Osmanlı vakıf düzeninin oluşması için her türlü ortam da hazırlanmıştı. Nitekim ilk vakıf da Sultan II. Selim tarafından açıldıktan sonra komutanlar ve diğer görevliler de vakıf faaliyetlerine girmişlerdir (Erdoğru, 2009, 58-64). Kıbrıs'ta ilk vakıf kurucuları, Padişah II. Selim, Lala Mustafa Paşa, Haydar Paşazade Mehmet Bey, Arap Ahmet Paşa, Pertev Paşa, Ağa Cafer Paşa gibi devlet erkânından hayırseverlerdi (Dündar, 1998, 222). Adaya fetih amaciyla gelen komutanlardan Haydar Paşa da kurduğu vakıfla Lapta bölgesinde su kemerleri tesis ederek Başpınar suyunu bölgeye getirmeye çalışmıştır (Yıldız, 1996, 98-99; Bağışkan, 2005, s. 397). Adada ilk dönem vakıfları içerisinde yer alan 18 adet su değirmeni günümüze ulaşmıştır (Soyel, \& Ahunbay, 2011, 111-112).

Kıbrıs yönetimine atanan idarecilerin çok sayıda vakıflar kurarak ada halkına hizmette bulundukları bilinmektedir. Adada en üst rütbeli yöneticiler valiler olduğundan en büyük vakıflar da bu görevliler vasıtasıyla teşekkül etmiştir. Dolayısıyla Kıbrıs valilerinin oluşturduğu vakıflar içerisinde su vakıfları da ayrı bir öneme haizdir.

Kıbrıs'ın ilk valilerinden olan Beylerbeyi Arap Ahmet Paşa, Lusignan ve Venedik dönemlerinde Lefkoşa Kalesi dışında bulunan suyu kente getirebilmek amacıyla Taht-el-kal'a (Tahtakale) yolunda kullanılan 2.400 parça künkten (su borusu) akan su tünellerinin bozulması dolayısıyla tamirat için kendi parasından 3.000 akçe tutarında bir miktarı ayırarak vakıf kurmuştur. Bu vakfa ait su yolu aksamının tamir ve inşasını 1594 yılında Zeynel b. Ali Reis yapmıştır (Jennings, 1993, 53; Y1ld1z, 1996, 94).

Arap Ahmet Paşa suyu olarak bilinen suyun ana kaynağı Lefkoşa'nın 4 km. güneyinde ve Stravolos'un 1,2 km. güneybatısındaki kuyulardan gelmekteydi (Bağışkan, 2005, 394). Lakadamya ve Deftera köyleri arasında kalan Kanlıdere'nin hemen batısında açılan kuyulardan sağlanan sular, kanallarla Kanlı Dere'yi takip eder ve Lefkoşa surlarındaki Değirmen (Tripoli) Burcuna ve Kaytaz Ağa (D'avila) Burcuna bir su kemeri köprüsüyle girerdi. Oradan da sur etrafında dönerek mahallelere ve çeşmelere dağıtılırdı.

1864 y1lı itibariyle Arap Ahmet Paşa suyundan Lefkoşa'ya toplam 118 masura ["masura", akarsu ölçüsünde kullanılan ve 4,5 debi (dakika/L)] miktarındaki sudur) (Çeçen, 1999, 55-70) su gelmekte ve bu su 62 ayrı yere dağıtılmaktaydı. En büyük payı da 16 masura su ile muhassıl sarayı almaktaydı. İkinci sırada ise 8 masura ile debbağhane almaktaydı. Lefkoşa'nın kale dışından gelen bu büyük vakıf suyundan Müslim-gayrimüslim ayırt etmeksizin faydalanılıyordu. Ermeni Kilisesi ve Ermeni haneleri 4 masura su almaktaydı (KŞS., 47, 36/1).

İlk su vakfi kurucularından biri de Baf Sancakbeyi Mehmet Bey b. Ebubekir'dir. 1592'de kurduğu vakıfla su kanalları, kemerler ve çeşmeler inşa ettirmiştir. Su vakıflarının gelirinin bulunduğu yerler Kasaba, Kurtaka, Lemona, Kato Panaya, Mesoyi, İpşata, Koloni, Malunda, Finike, Tsada, Pladanisya, Ksilohoryo, Nada, Shirona, Vasiliko, Falya, Aşşelya, Sindi, Celocedra, Tuzla, Kokkine, Piryan bölgelerindeydi (Altan, 1986, 511-512; 2003, 585-586). 
1607 yılında Kıbrıs Beylerbeyi olan Cafer Paşa, kendi adıyla kurduğu büyük vakıf teşkilatı içerisinde adanın su sorununa çare olmaya çalışmıştır. Bu kapsamda kendine ait sürüler, tarlalar, bağlar, zeytinlikler, evler ve dükkânlar yanında, bu mülklere bağlı suları da vakfetmiş (KŞS., 2/ 14/1; Gazioğlu, 2000, 251), ayrıca Mağusa'ya su götürerek su yolunun, çeşmelerin ve hamamın masraflarının vakıf gelirlerinden karşılanacağını vakfiyesine kayıt düşmüştü (Altan, 1986, 471; Yıldız, 1996, 97). Bugün Mağusa'da Cafer Paşa Çeşmesi ve Hamamı halen yapı olarak varlığını korumaktadir.

1738 yılında adaya gelen Richard Pococke, Mağusa'nın 7-8 mil kadar uzağında bulunan suyun kanallar ve kemerler ile şehre getirildiğine şahit olmuştur (Cobham, 1908, 255).

\section{Ebubekir Paşa Su Vakfi}

Vakıf yoluyla ada halkına hizmet eden valilerden en önemlilerinden biri büyük bir su vakfı tesis eden Ebubekir Paşa'dır. 1746 yılında Kıbrıs'a vali olarak atanan Hacı Ebubekir Paşa, adaya ilk geldiği dönemde Larnaka'da su bulunmadığını, bu sahil kasabasında halkın suyu iki saatlik yoldan taşıdıklarını büyük bir üzüntü ile görmüş ve bir an evvel bu duruma bir çare bulmaya karar vermiştir (Özoran, 1982, 27-29).

Ebubekir Paşa kurduğu büyük vakıf ile Arpera köyünde kuyular açtırarak Tuzla kazası ve İskele kasabasının şiddetle hissedilen su ihtiyacını gidermeye çalışmıştır (KŞS., 17, 90/1, H. 1161/M.1748). Bu bölge Avrupalı devletlerin Kıbrıs'ta bulunan konsolosluk temsilcilerinin ikamet mevkii ve önemli bir ticaret limanı olması dolayısıyla ayrı bir önem taşımaktaydı. O dönemde şehirde yaklaşık 700 hane bulunmakta ve nüfusun artışı dolayısıyla halk gün geçtikçe susuzluk çekmekteydi. Bu sebeple Kıbrıs'a üç tuğlu paşalıkla atanan Ebubekir Paşa 1747-1750 yılında bu sorunu çözmek üzere kendi parasıyla kuyu, köprü, kanal, çeşme yaptırarak bunları kurduğu Ebubekir Paşa Vakfı altında toplamıştır.

Ebubekir Paşa'nın kurduğu büyük vakfa bıraktığı emlak şöyleydi (KŞS., 17, 97/1; KŞS., 17, 100/2):

1) Sarayönü Camii yanında 23 dükkan,

2) Tuzla'nın Arpere köyünde İstavros bahçesi yanından ve yine aynı bahçe önünden akan derenin üstünden, Fransız tercümanı bâğçesi üstünden ve yeni açılan kuyulardan çıkan ve Tuzla merkez ve İskeleye gelen su,

3) Aynı suyun mecrâsı altında Kolonbo denilen mahalde ağaçlanı, bağı ve bahçesiyle birlikte 37 dönüm arazi ve dahilindeki buğday değirmeni,

4) Aynı suyun yolu altında Tuzla kasabasına yakın Aya Yorgi Manastırı yakınındaki köprünün karşısında bulunan buğday değirmeni,

5) Muhassıl sarayına bitişik vakfedilen dükkanların ardında inşa edilen büyük bir köşk,

6) 1000 zirâ avlu (duvar ve müştemilâtıyla),

7) Tuzla'nın Arpere köyünde vakfedilen bahçeye bitişik inşa edilen 12 oda ve bir ahırdan oluşan çiftliği (bütün müştemilâtıyla).

Ebubekir Paşa 1748 'de adadan ayrilırken yapılan tesisin henüz 2/3'si tamamlanmıştı. Adada geriye kalan işler için tahmini olarak 10 bin kuruşa ihtiyaç vardı. Paşa, vakıf işlerinin tamamlanması için zamanın saray tercümanı (dragoman) Hristofaci'ye (Christophakis) 14 bin kuruş para bırakmıştı. Ancak saray tercümanı Hristofaci vakıf inşaatını sürdürmeyerek işin tamamlanmasını sekteye uğratmıştır. Vakıf işlerini takip eden Ebubekir Paşa, Kıbrıs Defterdarı İsmail Efendi vasıtasıyla takibi sağlamaya çalışmış ve vakıf inşaatı ancak 1750 'de tamamlanırken tercüman Hristofaci dönemin valisi Hacı Baki tarafından öldürülmüştür (KȘS., 16, 225/2; Hill, 1952b, 76-77).

Ebubekir Paşa Vakfı kapsamında yapılan çalışmalarla Arpera köyünde birçok kuyular kazılmış, yöredeki pınarlardan suların bir mecraya sokularak kasabaya iletilmesi sağlanmış, pınarların yanlarına un değirmenleri yapılmış, suyun iletileceği yol boyunca dut ve diğer meyve 
fidanlıkları ile bağlar meydana getirilmiştir. Bu arada suyu şehre ulaştıracak olan üç büyük köprüyü destekleyecek kemerler de inşa edilmiştir. Köprülerden biri 50, diğeri 13 ve üçüncüsü 31 kemer üzerine oturtulmuştur. Toplam 93 kemerin desteklediği köprülerin yapılması için harcanan 50.000 kuruştan fazla para Bekir Paşa tarafından karşılanmıştır (Özoran, 1982, 27; Tosun, 2003, 87-91).

Yapılan çalışmalar sonunda Ebubekir Paşa, Larnaka'nın güneybatısında bulunan Trimito deresindeki kaynaklardan ve kuyulardan su getirmek üzere evlekler açtırmıştır. Evleklerin bir kısmı $10 \mathrm{~km}$. uzunluğundaki arazi düz olmadığı için taşları Kitium harabelerinden getirilerek özel olarak yaptırılan yerlerden yüksekliği 10,80 metre olan toplam 75 kemerin üzerinden geçirilmiştir. Kemerlerin üzerinde bir kanal içinden geçen su, yer seviyesine indiğinde üstü taş ve kireçle kapalı bir kanalda ilerleyerek Larnaka'ya ulaştırılmıştır (Özoran, 1982, 27).

Larnaka'ya getirilen suyun dağıtım yerinden sevki için gündelikleri on iki akçeli iki suyolcu istihdam edilmiştir. Suyun iki lülesi ("Lüle" dört masura su yerinde kullanılan bir tabir olup dakikada 36 litre miktarındadır ) bahçelerde sulamaya, geri kalan dört lülesi Larnaka'daki dört çeşmeye (her birine bir lüle), bir lülesi cami ve kale arasındaki çeşmeye, bir lülesi bir başka çeşmeye, iki lülesi Tuzla'da yaptırılan çeşmeye taksim edilmiştir (KŞS., 17, 90/1) (Vakfiyede, suyun şahıslarca evlere veya bahçelere hangi şartlarla satın alınabileceği; su borularının, değirmenlerin, çeşmelerin onarımı gerektiği zaman bunu bağ, bahçe ve değirmenlerden alınan kiralardan ayrılacak para ile yapılacağı; mütevellinin ve kâtibin onarımı en ekonomik şekilde yapmaları gerektiği; vakfın parasının israf edilmemesi gerektiği açıklanmıştır).

Ebubekir Paşa su vakfı sistemi, birbirlerine tünellerle bağlı olan çok sayıda su kuyusu, on çeşme, iki su değirmeni ve üç köprüden oluşmaktadır. Arpera Deresi yanında olan ilk su köprüsü en uzun olanıdır ve elli kemerlidir. Şu anda harabe halinde olan ikinci köprü on iki ve Larnaka yakınındaki üçüncü köprü ise otuz kemerlidir (Soyel, 2009, 36).

İskele kasabasına gelen sulardan değirmenler de istifade ederken bunlardan tahliye edilen sular ise bahçeleri sulamakta ve Tuzla'daki çeşmeleri şenlendirmekteydi (Soyel, 2009, 36).

1745 ve 1750 yıllarında adaya gelerek izlenimlerini anlatan Alexander Drummon, Ebubekir Paşa'nın kurduğu su vakfiyla ilgili olarak şu tasviri kaydetmişti:

"Bu iş için sıra kuyular kazdırmaya başladı ve kuyunun birinden ötekine
su götürdü. Bunu arazinin yüksek olduğu yerlerde yaptırdı. Çukur yerlerde
ise suyu kemerlerden geçirtti. İlk su yolu Arpera'dan gelmekte olup elli
kemerden oluşan bir yoldur. Bu kemerlerin ikisi küçük, ötekilerse dokuz
ayak genişliğinde olup en yükseği on iki ayak yüksekliktedir. Diğer ke-
merlerse arazi yükseldikçe giderek kaybolur. Kemer sütunlart sekiz ayak
genişliğinde ve üç ayak kalınlığındadır. İşte bu yörede paşa güzel dut
bahçeleri ve bir de bağ yetiştirip düşen sularla çalı̧̧an ve zahire üreten
bir de değirmen inşa ettirmiştir. Ikinci su kemerinin on iki kemeri olup
her biri on iki ayak genişliğindedir. Larnaka'nın yanında olan üçüncü
kemerse otuz bir kemerden oluşup her biri dört buçuk ayak genişliğinde,
en yüksekğinin yüksekliğiyle takriben on altı ayaktır. Her bir sütun dört
ayak kalınlığında ve on iki ayak genişliğindedir" (Gürkan, 2000, 175).

Ebubekir Paşa'nın Tuzla kasabası dışında kazdırmış olduğu vakıf sularının ihtiyaç fazlası, Tuzla kasabası halkına kiralanmaktaydı. 1845 yılı itibariyle bu şekilde kiralanan su miktarı 9,5 masura ve bir çuvaldız ("çuvaldız" su ölçü birimi olarak şemsiye telinin kalınlığında bir boyutu ifade ederken dakikada 1,125 litredir) olup bundan y1llık 152,5 kuruş gelir elde edilmekteydi (KŞS., $45,137 / 2)$. 
Tablo 1. 845 Yılı İtibariyle Ebubekir Paşa Vakıf Suyu Fazlası Kira Bedelleri (KȘS., 45, 137/2)

\begin{tabular}{|c|c|c|}
\hline $\begin{array}{l}\text { Çeşme-i hâne ve hamâm-1 Hacı } \\
\text { Abdülbaki Ağa der kasaba-i Tuzla } \\
2 \text { masura içme suyu ( } 20 \text { kuruş) }\end{array}$ & $\begin{array}{l}\text { Çeşme-i câmi-i şerîf ve Çeşme-i } \\
\text { hâne-i Hacı Abdülbaki Ağa ayak } \\
\text { suyundan müfrez her sene icâre } \\
\text { (10 kuruş) }\end{array}$ & $\begin{array}{l}\text { Çeşme-i hâne-i Feyzullah Efendi } \\
\text { b. Musîb Mehmed Efendi } 0,5 \\
\text { masura ( } 5 \text { kuruş) }\end{array}$ \\
\hline $\begin{array}{l}\text { Çeşme-i hâne-i Eci Anderliko } \\
\text { tercümân-1 İngiliz der-mahalle-i } \\
\text { Sotira mahal-i taksîmden ifrâz } \\
\text { mâ-i cârî1 masura (10 kuruş) }\end{array}$ & $\begin{array}{l}\text { Çeşme-i hâne-i Dük Gardan } \\
\text { Balyoz-1 Françelü der-mahalle-i } \\
\text { Hırsopolidise. Arabacılar içinde } \\
\text { vâki` terâzîden ifrâz mâ-i cârî } 2 \\
\text { masura (20 kuruş) }\end{array}$ & $\begin{array}{l}\text { Çeşme-i Makaryo v. Komi } \\
\text { Badyoş, Tuzla Erâmini. Kilise-yi } \\
\text { mezbûr Dördüncü terâzîden ifrâz } \\
\text { mâ-i cârî } 2 \text { masura ( } 20 \text { kuruş) }\end{array}$ \\
\hline $\begin{array}{l}\text { Çeşme-i hâne-i Giovanni Balyoz- } \\
1 \text { Dubrovnik Mâ-i cârî 0,5 masura } \\
\text { ( } 5 \text { kuruş) }\end{array}$ & $\begin{array}{l}\text { Çeşme-i hâne-i Nikola v. Piyeri } \\
\text { Mahall-i maksemden ifrâz mâ-i } \\
\text { cârî } 1 \text { çuvaldız (2,5 kuruş) }\end{array}$ & $\begin{array}{l}\text { Dörtyol ağzında vâki çeşmenin } \\
\text { fazla ve ayak suyundan deruhde-i } \\
\text { Haci Piyeri v. Zamarite tercü- } \\
\text { mân-1 Anapolitan (15 kuruş) }\end{array}$ \\
\hline $\begin{array}{l}\text { Arabacılar içinde vâki çeşmenin } \\
\text { ayak suyu demekle ma'rûf } \\
\text { fazlasından senede iki tezkere } \\
\text { mantûkunca deruhde-i Kossovî } \\
\text { Molla Hüseyin (15 kuruş) }\end{array}$ & $\begin{array}{l}\text { Çeşme-i hâne-i Yorgi Kalimira } \\
\text { der mahalle-i Aya Yani Yedinci } \\
\text { terâzîden ifrâz mâ-i cârî } 1 \text { masura } \\
\text { (10 kuruş) }\end{array}$ & $\begin{array}{l}\text { Çeşme-i hâne-i Antoni v. Mihail } \\
\text { mahall-i taksîmden üçüncü } \\
\text { terâzîden ifrâz mâ-i cârî } 0,5 \\
\text { masura( } 5 \text { kuruş) }\end{array}$ \\
\hline $\begin{array}{l}\text { Tuzla İskelesi’nde kale önünde } \\
\text { vâki çeşmenin ayak suyundan } \\
\text { malum'ul-mikdâr deruhde-i câmi- } \\
\text { i Hasan Ağa b. Hacı Abdülkadir } \\
\text { (2 kuruş) }\end{array}$ & $\begin{array}{l}\text { Tuzla İskelesi'nde mezâristân } \\
\text { kurbunde cârî çeşmenin ayak } \\
\text { suyu deruhde-i Nikola v. Bayri (5 } \\
\text { kuruş) }\end{array}$ & $\begin{array}{l}\text { Yine iskele-i mezkûrde kale } \\
\text { önünde vâki çeşmenin fazlası der- } \\
\text { uhde-i zaîm İsmail Ağa b. el-Hâc } \\
\text { Hasan ( } 8 \text { kuruş ) }\end{array}$ \\
\hline $\begin{array}{l}\text { Yine iskele-i mezkûrda kale } \\
\text { önünde vâki çeşmeden ifrâz } \\
\text { olunan su deruhde-i merkûm } \\
\text { İsmail Ağa mâ-i cârî } 0,5 \text { masura } \\
\text { ( } 5 \text { kuruş ) }\end{array}$ & & \\
\hline
\end{tabular}

Ebubekir Paşa suyunun fazlası belirtildiği üzere kiraya verilirken özellikle son dönemlerde bazı usulsüzlük iddialarına da konu olmuştur. 1868 yılında Tuzla iskelesine akmakta olan Ebubekir Paşa Vakfı suyunun eski Kıbrıs Evkaf Müdürü Arif Efendi tarafından yasadışı olarak bir takım kişilere satıldığ 1 vakıf mütevellisi Mustafa Rifat Bey tarafindan şikayet olunmuştu (KVGMA., Atik Emirname Defteri, 45/2). Ancak yapılan ayrıntılı tahkikat sonrasında Arif Efendi'nin faaliyetlerinde herhangi bir usulsüzlüğe rastlanılmadığı ortaya çıkmıştır (KVGMA., Atik Emirname Defteri, 106/1).

Ebubekir Paşa tarafından kurulmuş olan su vakıfları uzun yıllar Kıbrıs halkının ihtiyacını karşılamış, su yolunun aksamında bozulma olduğu zaman mütevellilerin talepleriyle gerekli düzeltmeler ve tamiratlar gerçekleştirilmiştir (KŞS., 21, 28/1, H. 1199/M. 1784; BOA., C.EV., 454/22988, H. 1199/ M.1784; BOA., MVL., 782/77, H. 1275/M. 1858).

Ebubekir Paşa tarafından açılan su vakfı tesisleri Batılı tarihçiler tarafından Osmanlı Dönemi'nde Kıbrıs'ta yapılan en değerli yapılar olarak nitelendirilmektedir (Hill, 1952b, 77; Purcell, 1968, 181; Luke, 1989, 68-69).

\section{Silahtar Mustafa Paşa Su Vakfı}

$\mathrm{Su}$ vakıfları kurarak Kıbrıs halkının, özellikle de Lefkoşa halkının su ihtiyacını sağlayan en önemli vakıf kurucularından biri de 1796-1798 yıllarında görev yapan (Çevikel, 2000, 338) Silahtar Mustafa Paşa olmuştur (KŞS., 28, 149/2). 


\section{[...] ashâb-ı hayrâtdan ve eslâf-ı kirâmınızdan muhassıl-ı esbak Silahdar Mustafa Ağa merhûm müceddeden kuyular hafriyla mahrûse-i mezbûreye Silahdar suyu demekle şöhret-yâb-ı âcir-tâb eylediği mahrûse-i mezbûre mâ-i lezizine [...]}

Vakfın su kaynağı Lefkoşa'nın 1,5 km. kadar güneyindeki Cikko Manastırı Medoşu ile Ayii Omoloyitadhes bölgesi arasında yer almaktaydı (Bağışkan, 2005, 395). Bu sudan 1814 yılında Kaymaklı köyü halkına ilk kez su verilmeye başlanmıştır. Bu tarihte köy, şiddetli susuzluk çekmekte olduğundan mahkemeye gelerek "Silahtar Suyu" olarak bilinen eski Kıbrıs valilerinden Silahtar Mustafa Paşa tarafından açtırılan vakıf suyundan faydalanmak istediklerini bildirmişlerdir. Köy halkı vakfa, açacakları yeni yedi kuyu suyunu ve 500 kuruş vakfederek, çıkacak suyun yarısını kendi köylerine, yarısını da vakfa bırakılması şartlarıyla su verilmesini talep etmişti. Bu talep, dönemin Kıbrıs muhassılı bulunan Esseyyit Mehmet Emin Efendi’ye iletilmiş ve kabul görmüştü (KŞS., 28, 149/2).

Bu vakfın 1860'lı yıllarda artık pek bir gelirinin kalmadığı anlaşılmaktadır. 1865 yılında su yolunun harap olmasından ötürü tamir ve bakımı gerektiğinde gelir yetersizliğinden tamir masraflarını hazine üstlenmişti (BOA., MVL., 797/13).

\section{Diğer Su Vakfi Kurucuları}

Eski Kıbrıs muhassıllarından 1799-1802 yıllarında görev yapan Hüseyin Ağa (Dinç, 2010, 135) 1801-1802'de (1216) İncirli köyü sınırında 113 su kuyusu açtırarak büyük bir su vakfi tesis etmişti (BOA, 2010, 225). Bu sudan "vakf-i sahih-i şer '厃̂" ile 10 masura içme suyunun dokuz masurası Lefkoşa'da Cami-i Cedid camii şadırvanına, diğer bir masurası da yıllık on kuruş kira ile aynı mahallede bulunan Sarı Ali Ağazade Süleyman Efendi evine kiralanmaktaydı. Ancak 1813 yılı sonunda, Süleyman Efendi hanesine giden su yolunun zamanla bozulması hem de vakıf mütevellisinin ifadesiyle; bu evin miras yoluyla kendisine kalması, ancak kendisinden sonra eve sahip olacakların su yolunun bakımıyla ilgilenmeyecekleri endişesiyle vakıf suyunun buradan alınıp başka birine kiralanması kararlaştırıldı. Bu amaçla suyun 3/4'ü beş yüz kuruş muaccele ve yıllık 5 kuruş icâre-i müeccele ile Müftüzâde Esseyyit Hasan Efendi'ye teslim edilmiş̧i (KŞS., 28, 163/2).

1817 yılında Kıbrıs muhassılı bulunan Seyyit Mehmet Emin Efendi, 1.500 kuruşunu Ömeriyye Camisi bitişiğindeki Makam-ı Hızır'ın kandil masraflarına, Tuzla yolunda kendisinin yaptırdığı çeşmenin su yolları ve diğer masraflarına, yine Girne kasabasında yaptırdığı iki çeşmenin su yolları ve diğer masraflarına, Ömeriyye Camii'nde mevlid-i şerif ve Kur'ân okuyanların masraflarına ve mütevelliye sarfedilmek üzere vakfedip, mütevelliliğine Emirülhac Mehmet Ağa b. İsmail'i tayin etmişti (KŞS., 29, 132/1; KVGMA, Kara Kaplı Vakfiye Defteri, 216/1, H. 1232/M. 1817).

1818 y1lında Muhassıl Seyyit Mehmet Emin Efendi’nin hizmetçilerinden Kemahlı Bilal Ağa b. Hasan Ağa, bin sekiz yüz kuruşunu Maraş'ta yaptırdığı caminin görevlilerine, tamirine ve diğer masraflarına, Leymosun'daki Zincirlikuyu Camisi etrafinda bulunan su kuyularının temizlenmesi ve su yollarının tamirine ve diğer ihtiyaçlarına onu on bir buçuk hesâbı üzere vakfedip, Haydar Paşa Camisi Müderrisi Mehmed Efendi b. Abdullah'ı mütevelli tayin etmişti (KŞS., 29, 209/1).

Lefkoşa mahkemesinin su ihtiyacı da çoğu zaman hâkimlerin açtırdıkları su kuyuları sayesinde karşılanıyordu. 1806 yılında mahkeme naibi bulunan Eseyyit Hâfız İbrahim Ethem Efendi Lefkoşa dışında kazdırdığı kuyudan çıkan suyu mahkemeye getirebilmek için, fazlası Ayasofya Camisine bırakılması karşılığında vakıf su yolunu kullanma izni almıştı (KŞS., 26, 12/3). 


\section{Kıbrıslıların Kurdukları veya Yardımda Bulundukları Su Vakıfları}

Vakıf kurabilmek herşeyden önce ekonomik durumla ilgili olduğundan birçok zengin Kıbrıslı'nın var olan vakıf suyunun devamını sağlamaya çalıştıkları izlenmektedir. Burada belirtilmesi gereken husus, yapılan desteğin evlerde veya işyerlerinde ihtiyaç duyulan su, açılan kuyu sularını getirmek için vakıf su yollarına yapılan destekle bağlantılıdır.

Lefke bölgesi denize kadar uzanan verimli tarlaları ile Kıbrıs'ın önemli tahıl üretim merkezlerinden biriydi. Hâsıl olan tahılın ögütülmesi için birçok değirmen ve su gerzleri inşa edilmiştir. Bunlardan başka narenciye bahçelerini sulamak üzere Trodos dağından gelen su hendeklerle tüm şehre dağıtılmıştır. Lefke'ye gelen su, Elhac Ali Efendi b. Ebubekir Efendi tarafından kurulan vakıf kapsamında inşa edilmiştir. Elhac Ali Efendi 1690 yılında satın aldığı hamam ve Muratasa deresinde olan hakkını bahçelerin "hakk-ı şirbi" (Pakalın, 1990, 357, Hakk-ı şirb, su içmek, ekin veya hayvan sulamak için sudan faydalanma nöbeti anlamına gelmektedir) için sekiz saatlık hakkını kurduğu vakfa ayırmış ve su kemerleri inşa ettirerek bahçelerde kullanılan suyun dağıtımını kolaylaştırmıştır (Yıldız, 1996, 98; Gazioğlu, 2000, 251-252).

1773 (H. 1186) yılında Lefkoşa'nın Ömeriye mahallesinden Hacı Ahmet b. Recep, Unpazarı mahallesindeki dükkânını müştemilatıyla birlikte kendi parasıyla tamir ettirdiği Sünbülî Çeşmesi'nin su yollarında meydana gelecek bozulmalarda kullanılmak üzere vakfetmiş ve Hırsofi'nin Malatya köyü imamı Mustafa Efendi b. Hüseyin'i mütevelli tayin etmişti. Dükkan "icâre-i sahîha" ile kiralanarak hâsıl olacak gelirle çeşmenin su yolları gerektiğinde tamir edilecekti (KVGMA., KKVD, 122/1).

Lefkoşa'nın Ömeriye Mahallesi'nden Yasakçızade Yusuf Ağa b. Ali vefat ettiğinde, ölmeden önce malının 1/3'ü vakfetmek üzere Bakkalbaşı Hacı Hüseyin Ağa b. Mehmet'i vasi tayin etmişti. Bakkalbaşı Hacı Hüseyin Ağa b. Mehmet bu durum için Şevki Efendi b. Hacı Halil Efendi ve İbrahim Efendi b. Perdahtcı Ali'yi şahit göstermiş ve durum mahkemece kabul edilmişti. Bakkalbaşı 16.516 kuruşu varislerden aldıktan sonra önce bunun 6.516 kuruşunu bazı vakıflara harcamış, kalan 10 bin kuruşunu da istirbah ederek mütevellisine yıllık 150 kuruşluk tevliyet hakkına, kalanını da Silahtar suyunun su yolları ile Eğlence köyündeki çeşme ve Tuzla yolundaki çeşmenin tamirlerine vakfederek kendisini mütevelli tayin etmişti (KŞS., 47, 148/1, H. 1283/M. 1866-1867).

1863-1864 (1280) yılında Dağ kazasında Lakadamya köyünde bulunan evkaf sularını toplam 34 ayrı kişi tarla ve bahçe sulama amacıyla belirli saatlerle kullanım için "icare-i vahide" (Ömer Hilmi Efendi, 2003, 42-43) ile kiralamıştı. Bu vakıf suyunu kiralayanlar Mehmed Efendi b. Hacı Hüseyin $(117,5)$, Münîb Efendizâde kerîmesi Emine Hanım (27 saat 45 dakika), Emetullah Hanım (27 saat 45 dakika), Çoban Mehmed oğlu Ahmet (6 saat), Halil b. Hasan (6 saat), Mihail v. Zandi (6 saat), Haralanbo v. Mihail (5 saat), Haci Gavril v. Zandi (6 saat), Haci Dimitri oğulları Mihail ve Haralanbo (6 saat), Dimitri v. Haci Mihail (12 sat), Ahmed b. Abdullah (2 saat), Hasan ve Hüseyin bin İsmail (4 sat), Haci Hristoğlu v. Luizi (6 saat), Maryana bint-i Penai (3 saat), Haci Haralanbo v. Nikola (11 saat), Kiryaki ve kız karındaş1 Resino (2 saat), Nikola v. Ligori (1 saat), Praşoko bint-i Ligori (1 saat), Eftemyo v. Haci Sava (3 saat), Haci Kiryako v. Haci Ebkeri (5 saat), Hâfız Hüseyin Efendi b. Halil (4,5 saat), Mustafa b. İbrahim (4,5 saat), Efrosni bint-i Mihail (3 saat), Luizi v. Antoni (3 saat), Maro bint-i Antoni (2 saat), Savi v. Yorgi (3 saat), Haralanbo v. Haci Gavril (3 saat), Penai bint-i Ferağnosya (3 saat), Hristoğlu v. Nikola (2 saat), Yorgancı Hacı İbrahim ve karındaşı Ahmed (6 saat), Pâpûşcu Mehmed ve karındaşı (6 saat) idi (KVGMA., Küçük Vakfiye Defteri, 28/1).

Bunlardan başka Mustacızâde (1806), Piskopulu Hacı Keleş Efendi (1814), Köprülü Hacı İbrahim Ağa (1825), Hacı İsmail Ağa (1838), Mesut Hasbi Efendiler ve daha birçok kişi kendi adlarında kurdukları vakıflar içerisine adanın muhtelif bölgelerinde olan su haklarını vakfederek 
halkın su ihtiyaçlarına çare olmaya çalışmışlardır (Gazioğlu, 2000, 252).

\section{Vakıf Su Yollarının Tamiri}

Kıbrıs'ta su vakfi kurmak ve var olanlara maddi yardımda bulunmak önemli olduğu gibi mevcutların devamını sağlamak da ayrıca bir ehemmiyet arzetmektedir. Bu anlamda daha önce kurulmuş bulunan su vakıflarının aksamlarının bozulan bölümlerinin yenilenmesi zorunluluğu ortaya çıkmaktaydı. Mahkeme kayıtlarında özellikle vakıf su yollarının tamirine dair çok sayıda hüküm bulunmaktadır. Vakıf suları tamir kayıtlarında tamir veya yenileme masrafları mütevellilerin talebi doğrultusunda vakıf gelirlerinden karşılanmaktaydı. Harcamalar eskiden beri alınan gelirlerden oduğu gibi vakfa yeni bağlanan gelirlerden de karşılanabilmekteydi.

$\mathrm{Su}$ yollarının zamanla bozulmaları halkın su ihtiyacını karşılamasını zorlaştırmaktaydı. $\mathrm{Bu}$ nedenle Osmanlı İmparatorluğu'nda uzak bölgelerden şehirlere getirilen suların su yollarının yenilenmesi, tamir edilmesi ve temizlenmesi, üzerinde önemle durulan hususlardan olmuştur. $\mathrm{Bu}$ durum su yollarıyla ilgili bir teşkilatın oluşmasını sağlamıştır. Suyolculuk mesleği bu teşkilat içinde en önemli görevlerdendir. Suyolcular, suyun kaynăğndan itibaren başlayarak kanal ve künklerle yerleşim birimlerine getirilmesi, suyollarının yapılması, bozulan suyolları ve çeşmelerinin onarılması, suların çeşmelere düzenli akıtılması ve benzeri hizmetleri ifa eden görevliler$\operatorname{dir}$ (Martal, 1989, 1587).

Suyolcularının su vakıfları yönünden önemli sayılması dolayısıyla bu görevlilere vakfiyelerde ödemeler yapılması hükme bağlanmıştır. Kıbrıs muhassılı Süleyman Efendi (1766) Lefkoşa halkının su ihtiyacı için su kuyuları kazdırmış ve bunlara bağlı bir de çeşme yaptırmıştı. Bunların bakım ve tamiri için de şehirdeki dükkanını vakfederken bu işle ilgilenecek suyolcusuna ayda 20 para verilmesini vakfiye şartı olarak belirtmişti (KŞS., 19, 27/1).

Aralık 1834 (Şaban 1250) tarihinde Lefkoşa'ya gelen içme suyunun kale haricinde bulunan ve tamire muhtaç olan yollarının temizlenmesi ve islahı için yapılan çalışmada suyolcuya 43 günlük çalışma için 129 kuruş ödenmişti (KŞS., 35, 157/1).

Suyolcuları sadece su yollarının tamir ve bakımından sorumlu değildir; aynı zamanda sularla ilgili ortaya çıkan sorunlarda bilirkişilerle birlikte tespitlerde bulunarak mahkemelerin adaletli tecelli etmesini de sağlarlar. Örneğin Lefkoşa'nın Arap Ahmet Paşa Mahallesi'nden Ramazan Çelebi b. Hüseyin kendi evine getirdiği vakıf suyuna karşılık yaptırdığı su kuyularındaki mevcut su miktarı bilirkişiler ve Lefkoşa'da bulunan hassa suyolcular Ahmed b. Abdullah ve Hıristofi v. Gavrail tarafından belirlenmişti (KŞS., 9, 53/5, H.1130/M. 1717).

Tablo 2. Kıbrıs'ta Görev Yapan Suyolcular

\begin{tabular}{|l|c|c|l|l|}
\hline \multicolumn{1}{|c|}{ Adı } & Görev Aldığı Vakıf & Ücreti & \multicolumn{1}{|c|}{ Tarihi } & \multicolumn{1}{c|}{ Kaynak } \\
\hline Cafer Bey & - & - & $\begin{array}{l}\text { H. 1 Muharrem 1046/M. 5 } \\
\text { Haziran 1636 }\end{array}$ & KŞS., 4, 160/4 \\
\hline Komi & - & - & $\begin{array}{l}\text { H. 15 Zilhicce 1125/M. 2 } \\
\text { Ocak 1714 }\end{array}$ & KŞS., 8, 21/1 \\
\hline $\begin{array}{l}\text { Ahmed b. } \\
\text { Abdullah }\end{array}$ & - & - & $\begin{array}{l}\text { H. 1 Muharrem 1130/M.5 } \\
\text { Aralık 1717 }\end{array}$ & KŞS., 9, 53/5 \\
\hline $\begin{array}{l}\text { Huristofi v. } \\
\text { Gavrail }\end{array}$ & - & - & $\begin{array}{l}\text { H. 1 Muharrem 1130/M. } \\
\text { M.5 Aralık 1717 }\end{array}$ & KŞS., 9, 53/5 \\
\hline Mehmed & - & - & $\begin{array}{l}\text { H. 21 Zilkade 1132/M. 24 } \\
\text { Eylül 1720 }\end{array}$ & KŞS., 10, 50/1 \\
\hline Süleyman & - & - & $\begin{array}{l}\text { H. 9 Muharrem 1140/M. 27 } \\
\text { Ağustos 1727 }\end{array}$ & KŞS., 13, 30/4 \\
\hline
\end{tabular}




\begin{tabular}{|c|c|c|c|c|}
\hline Süleyman & $\begin{array}{l}\text { Lefkoşalı Hacı İsmail } \\
\text { Ağa b. Hacı Ramazan } \\
\text { Ağa'nın vakfına ait } \\
\text { Ayasofya Câmi'-i } \\
\text { Şerîfinde }\end{array}$ & $\begin{array}{l}\text { Günlük } 2 \text { çürük } \\
\text { akçe }\end{array}$ & $\begin{array}{l}\text { H. } 1 \text { Receb 1141/M. } 31 \\
\text { Ocak } 1729\end{array}$ & $\begin{array}{l}\text { KVİA., Küçük } \\
\text { Vakfiye Defteri, } \\
\text { 112/1 }\end{array}$ \\
\hline Yorgi & $\begin{array}{l}\text { Lefkoşalı Hacı İsmail } \\
\text { Ağa b. Hacı Ramazan } \\
\text { Ağa'nın vakfına ait } \\
\text { çeşmelerde }\end{array}$ & $\begin{array}{l}\text { Günlük } 4 \text { çürük } \\
\text { akçe }\end{array}$ & $\begin{array}{l}\text { H. } 1 \text { Receb 1141/M. } 31 \\
\text { Ocak } 1729\end{array}$ & $\begin{array}{l}\text { KVİA., Küçük } \\
\text { Vakfiye Defteri, } \\
\text { 112/1 }\end{array}$ \\
\hline $\begin{array}{l}\text { Hac1 } \\
\text { Süleyman }\end{array}$ & - & - & $\begin{array}{l}\text { H. } 29 \text { Cemaziyelahir } \\
\text { 1163/M. } 5 \text { Haziran } 1750\end{array}$ & KŞS., 16, 225/2 \\
\hline Elhac Ali & - & - & $\begin{array}{l}\text { H. } 6 \text { Ramazan 1159/M. } 22 \\
\text { Eylül } 1746\end{array}$ & KŞS., 17, 58/2 \\
\hline Hasan & - & - & $\begin{array}{l}\text { H. } 6 \text { Ramazan 1159/M. } 22 \\
\text { Eylül } 1746\end{array}$ & KŞS., 17, 58/2 \\
\hline Ahmet & - & - & $\begin{array}{l}\text { H. } 6 \text { Ramazan 1159/M. . } 22 \\
\text { Eylül } 1746\end{array}$ & KŞS., 17, 58/2 \\
\hline- & $\begin{array}{l}\text { Muhassıl Süleyman } \\
\text { Efendi'nin yaptırdığı } \\
\text { Lefkoşa'da çeşme ve } \\
\text { su yolunda }\end{array}$ & Aylık 20 para & $\begin{array}{l}\text { H. } 1 \text { Receb 1180/M.3 Aralık } \\
1766\end{array}$ & KŞS., 19, 27/1 \\
\hline Hasan & - & - & $\begin{array}{l}\text { H. } 5 \text { Şevval 1180/M. } 6 \text { Mart } \\
1767\end{array}$ & KŞS., 19, 45/1 \\
\hline $\begin{array}{l}\text { Süleyman } \\
\text { b. Mustafa }\end{array}$ & - & - & $\begin{array}{l}\text { H. } 1 \text { Zilhicce 1203/M. } 23 \\
\text { Ağustos } 1789\end{array}$ & KŞS., 19, 153/2 \\
\hline Mustafa & - & - & $\begin{array}{l}\text { H. } 29 \text { Receb 1184/M. } 18 \\
\text { Kaim } 1770\end{array}$ & KŞS., 20, 14/3 \\
\hline Hacı Ali & - & - & $\begin{array}{l}\text { H. } 6 \text { Cemaziyelevvel } \\
\text { 1184/M. } 28 \text { Ağustos } 1770\end{array}$ & KŞS., 20, 28/1 \\
\hline $\begin{array}{l}\text { Koca } \\
\text { Elhac } \\
\text { Mehmet }\end{array}$ & - & - & $\begin{array}{l}\text { H. } 29 \text { Cemaziyelevvel } \\
\text { 1210/M. } 11 \text { Aralık } 1795\end{array}$ & KŞS., 21, 322/2 \\
\hline- & Saray arıkları içün & 8 kuruş 10 para & $\begin{array}{l}\text { H. Muharrem } 1222 \text { /M. Mart } \\
1807\end{array}$ & KŞS., 25, 34/4 \\
\hline $\begin{array}{l}\text { Usta } \\
\text { Süleyman }\end{array}$ & - & - & $\begin{array}{l}\text { H. } 5 \text { Rebiülâhir 1230/M. } 17 \\
\text { Mart } 1815\end{array}$ & KŞS., 28, 250/3 \\
\hline- & $\begin{array}{l}\text { Seyyid Elhac Mehmed } \\
\text { Ağa vakfiyesi }\end{array}$ & Yillık 49 kuruş & $\begin{array}{l}\text { H. } 29 \text { Şevval 1232/M. } 11 \\
\text { Eylül } 1817\end{array}$ & KŞS., 29, 169/2 \\
\hline- & $\begin{array}{l}\text { Muhassıl Ali Rûhi } \\
\text { Efendi'nin Lefkoşa'da } \\
\text { Abdi Çavuş } \\
\text { Mahallesi'nde } \\
\text { yaptırdığı cami vakfı }\end{array}$ & Günlük 4 akçe & $\begin{array}{l}\text { H. } 5 \text { Cemâziyelâhir 1243/M. } \\
24 \text { Aralık } 1827\end{array}$ & KŞS., 33, 28/1 \\
\hline- & $\begin{array}{l}\text { Lefkoşa'ya gelen vakıf } \\
\text { suları }\end{array}$ & $\begin{array}{l}43 \text { gün } 129 \\
\text { kuruş }\end{array}$ & $\begin{array}{l}\text { H. } 13 \text { Şaban 1250/M. } 15 \\
\text { Aralık } 1834\end{array}$ & KŞS., 35, 112/1 \\
\hline Ali & - & - & $\begin{array}{l}\text { H. } 14 \text { Rebiulahir 1260/M. } 3 \\
\text { Mayıs } 1844\end{array}$ & KŞS., 39, 140/1 \\
\hline
\end{tabular}




\begin{tabular}{|l|c|c|l|l|}
\hline İsmail Ağa & - & - & $\begin{array}{l}\text { H. 21 Cemaziyelahir } \\
\text { 1286/M. 28 Eylül 1869 }\end{array}$ & KŞS., 49, 179/1 \\
\hline $\begin{array}{l}\text { Hacı } \\
\text { Ahmet }\end{array}$ & - & - & $\begin{array}{l}\text { H. 9 Zilkade 1288/M. 20 } \\
\text { Ocak 1872 }\end{array}$ & KŞS., 50, 142/2 \\
\hline Ali Day1 & & & $\begin{array}{l}\text { H. 22 Cemaziyelevvel 1290 } \\
\text { /M. 18 Temmuz 1873 }\end{array}$ & KŞS., 51, 100/2 \\
\hline- & Cafer Paşa Evkafinda & $\begin{array}{l}\text { İki suyolcudan } \\
\text { birine günlük 4, } \\
\text { diğerine 3 akçe }\end{array}$ & $\begin{array}{l}\text { H. 28 Şevval 1280 /M. 6 } \\
\text { Nisan 1864 }\end{array}$ & $\begin{array}{l}\text { KVİA., Küçük } \\
\text { Vakfiye Defteri, } \\
11 / 1\end{array}$ \\
\hline
\end{tabular}

Su vakıflarının işleyişinde yardımcı olan diğer görevliler nazır, kethüda, mühendisler, keşif memurları, korucular, çavuşlar, halife, bent memurları, çeşmeciler idi. Ancak bunlar daha çok İstanbul ve diğer büyük şehirlerin suları için geçerli görevlilerdi (Güneri, 1971, 70; Çelik, 2006, 307; Karataş, 2008, 393). Ancak Kıbrıs'ta incelenen belgelerde bu görevlilere rastlanılamamıştır. Muhtemeldir ki bu vazifeleri suyolcular yerine getirmekteydiler.

Vakıflara ait su yollarının gerektiğinde bakımlarının yapıldığı anlaşılmaktadır. Örneğin 1677 yılında Cafer Paşa evkafından olup Esimof köyünde bulunan çiftliğe su götüren yollarının bozulması dolayısıyla mütevelli Recep Bey'in yapılacak keşif sonunda ortaya çıkacak neticeye göre bozulan kısımların vakıf gelirlerinden tamir edilmesi isteği mahkemece uygun bulunmuştu (KŞS., 5, 45/2, H. 1088/M. 1677).

Ebubekir Paşa tarafindan kurulan büyük su vakfına gelir sağlayan çiftliklerde yaşayan reâyânın zamanla vergilerden dolayı perişan kalmalarından ötürü durumlarının düzeltilmesi için 1768 ve 1785 yıllarında iki ayrı dilekçe sunulmuştur. Çıkarılan fermanlarda Ebubekir Paşa'nın Tuzla ve Larnaka için yaptırdığı içme suyunun tamir ve bakım masrafları için vakfettiği çiftliklerin yirmi beş reâyâsından toplam verecekleri iki yüz dört buçuk kuruştan fazla bir para istenmemesi gerekirken kendilerinden yirmi beş reâyânın her birinden 25'er kuruş talep olunduğu, bu sebeple reâyâdan on dördünün çiftliklerden ayrıldı̆̆ 1 , geriye kalan on birinin mevcut vergiyi ödemeye tahammülleri olmadığından vakfın kapanmasına yol açabileceği, hatta su yolundaki dört kemerin tamamıyla harap hale geldiği ve bunun için en az bin kuruş gerektiği anlaşıldığından vakıf mütevellisi ve nazırlarına çiftliklerin tekrar düzenlenip verimli hale getirilmeleri için hüküm yazılmıştı (KŞS., 19, 62/1, H. 1181/M. 1767-1768; KŞS., 21, 28/2, H. 1199/M. 1785-1786).

Ebubekir Paşa'nın su yollarının tamiri için Paşa Çiftliği 10 yılda bir kiraya verilmek suretiyle işletilmekte ve kira geliri su yolunun tamiratına harcanmaktaydı. Bu çiftlik 1855-1856'de (1274) yıllık 9.250 kuruşa ile Hilmi Efendi'ye (BOA., A.AMD., 85/76), 1867'de yıllık 20.000 kuruşa Tuzlalı İbrahim Efendi'ye kiralanmıştı (KVGMA., Atik Emirname Defteri, 4/1).

Bekir Paşa su kemerinin Hala Sultan Tekkesi civarında bulunan bir bendinin 1863 yılında sel sularından hasar görmüş ve tamirat için mühendis yüzbaşılardan Şükrü Efendi görevlendirilmişti (Soyel, 2009, 36).

Mehmet Paşa evkafindan Lefkoşa'da bulunan vakıf çeşmelerinin su yolları tamiri ve yeni kazdırılan 8 kuyunun yüz otuz iki kuruşluk masraflarının vakıf gelirlerinden karşılanması sağlanmıştı (KŞS., 14, 127/2, H. 1144/M. 1731-1732).

Vakıf sularının tamir masrafları vakfa yeni sağlanacak gelirlerle de olabiliyordu. 1791 senesinde Mağusa kalesi yakınında Kızılkaya adlı bölgeden gelen vakıf içme suyunun tamir ve bakımı için vakıf kurucuları tarafından herhangi bir gelir tahsis edilmediğinden su yolunun bakımsızlığından şikâyet olunmuştu. Hatta halk yeterli su bulunmadığında oldukça perişan bir hale düşmüştü. Çözüm olarak da adı geçen sudan Korkut Hamamı'na belirli bir miktar su verile- 
rek elde edilecek gelirle su yolları ve çeşmelerin tamiri sağlanmıştır. Ayrıca bu işle ilgilenecek su yolcuya da aylık altmış para ücret ödenmişti (KŞS., 21, 177/3, H. 1205/M. 1790-1791).

Lefkoşa'nın Ayasofya Mahallesinden şehbender Esseyyit Ömer Efendi b. Esseyyit Ali kendi parasından 500 kuruşu Haydarpaşa camii avlusunda bulunan ahalinin abdest almak için getirilen suyun yol tamiri masraflarına harcanması için vakfetmişti. Esseyyit Ali onu onbir buçuk (\% 15) üzere gelir elde edilecek olan paradan aylık 20 kuruşunun su yolu tamirine ve suyla ilgilenen kişiye de aylık üçer kuruş verilmesini ve geriye kalanının mütevelli olanlara bırakılmasını şart koşmuştu (KŞS., 41, 148/2, H. 1264/M. 1848).

Vakıf sularının, yol, çeşme, kuyu vb. gibi aksamlarının tamirleri son dönemde yapılan düzenlemelerle Evkaf Sandıkları'ndan da karşılanmaya başlanmıştır. Özellikle Lefkoşa şehrine su getiren Arap Ahmet Paşa ve Silahtar su vakıfları bu anlamda desteklenmiştir. 1863 yılında yolları bozulan ve tamire muhtaç olan Arap Ahmet Paşa su yolunun tamiri için özel bir komisyon oluşturulmuştur. Komisyonun çalışmaları sonunda bakım ve onarım için nelerin gerekli olabileceğinin ortaya çıkarılması istenilmişti. Bu amaçla mühendisler tarafından yapılan keşif masrafı olan 500 kuruş Evkaf sandığından karşılanmıştır (KVGMA., Atik Emirname Defteri, 180/1).

Arap Ahmet Paşa suyunda 1860'lı yıllarda hem kaynağının hem de su yollarının bozulması dolayısıyla bakım ve tamire ihtiyaç duyulmaktaydı. Fakat vakıf gelirleri tamir için gerekli 30.000 kuruşluk masrafı karşılamaya kâfi gelmediğinden bu miktarın yarısının su sahiplerinden, diğer yarısının da Evkaf Sandı̆̆ı'ndan karşılanması emredilmiş̧i. (KVGMA., Atik Emirname Defteri, 48/1; BOA., TŞR.KB.UM., 236/56) Alınan emir üzerine Kıbrıs Mutasarrıflı̆̆ı'ndan Kıbrıs Evkaf Müdüriyeti'ne yazılan yazıda 12.134,5 kuruşun bir an önce verilmesi gerektiği bildirilmişti (KVGMA., Atik Emirname Defteri, 49/1).

1875 yıllında da benzer biçimde vakıf su kuyuları tamir masrafları Evkaf Sandığı''ndan karşılandıktan sonra gerekli tahsilat sağlanmış ve 4.975 kuruş Sandığa yatırılmıştı (KVGMA., Küçük Vakfiye, 140/1).

\section{Su Vakıflarıyla Yaşanan Sorunlar ve Müdahalelerin Önlenmesi}

Kıbrıs su vakıflarıyla ilgili ortaya çıkan en önemli sorun vakıfların ortadan kalkmasına sebep olabilecek müdahalelerin engellenememesiydi. Adada en önemli hususlardan biri su olduğundan buna ilişkin vakıfların devamı ayrı bir önem taşımaktaydı. Dolayısıyla su vakıflarının zararına yapılan müdahalelerin engellenmesi merkezî hükümet ve Lefkoşa mahkemesi tarafından sıklıkla dile getirilen bir hususdur.

$\mathrm{Bu}$ konuya dair ilk örneklerden biri Mustafa Paşa evkafına ait suya müdahaleyle ilgilidir. Lefkoşa'da Darüssaade Ağası Yusuf Ağa nezaretinde bulunan Mustafa Paşa evkafindan olup Ömeriye camiine vakfedilen suya Kıbrıslı Mustafa adlı çorbacı kendi gelirlerinden on adet kuyu kazdırmış ve çıkan suyun yarısını camiye, diğer yarısını da kendi hanesine aktarmıştır. Ayrıca vakfa her yıl 360 akçe ücret ödeyen Mustafa su yollarını da kendi gelirlerinden tamir ettirmiştir. $\mathrm{Bu}$ sebeple vakıfla ilgili işlerde kendisine müdahale olunmaması talebini uygun bulunarak başkalarınca müdahale edilememesi uyarısı yapılmıştır (KŞS., 5, 86/2, H. 1088/M. 1677).

Lefkoşa'da halkın en fazla faydalandığı sular Ayasofya ve Ömeriye camileri için şehre getirilen su vakıflarına aitti. Dolayısıyla bu sularda çoğu kişinin müdahalesi söz konusu olabiliyordu. Örneğin 1717-1718'de (1129) Ayasofya ve Ömeriye camileri mütevellilerin bazılarının suları başka hanelere sattıkları haber alınmış, ancak padişah beratı olmaksızın vakıf sularının dişarıya verilmesi yasak olduğundan, yaşanan durumun kesinlikle önüne geçilmesi istenilmişti. Zira sular uygun olmayan biçimde hanelere aktarıldığında zaman zaman camilere su gelmiyor ve ahali sıkıntı çekiyordu (KŞS., 9, 51/2). 
Lefkoşa'da Korkut Efendi Hamamı sahibi Fatma Hatun, hamamına gelen suyun kuyularının temizliği için her yıl Haremeyn-i Şerîfeyn mütevellilerine yedi kuruş ücret ödemekteydi. Ancak 1732 (Şevval 1144) yılında mütevellilerin fazla olarak 40 kuruş ücret talep etmeleriyle Fatma Hatun Divan-1 Hümayun'a arzuhal sunarak durumun düzeltilmesini istemişti. Konu ile ilgili yazılan fermanda vakanın mahkemede görülerek vakıf tarafına bir haksızlık yaşanmamasına özen gösterilmesi gerektiği açıklanmıştı (KŞS., 14, 87/2).

Girne kazasına bağlı Lapta köyünün suyu bölgede bulunan Haremeyni'ş-Şerîfeyn evkafı mütevellisi tarafından idare edilmekteydi. Vakıf mütevellisince yönetilen su her üç yılda bir senedi yenilenmek suretiyle köyün kullanımına kiralanmaktaydı. 1786-1787 (H. 1201) senesinde senedin yenilenme zamanı geldiğinde yine eskiden beri olduğu üzere köy halkına kiralanması düşünülmüştü. Ancak köy halkından Hacı Kasım oğlu Abdurrahman ve Cin Hasan oğlu İbrahim'in kira bedelini yarıya indirmek istemişler, bu ise vakfı zarara uğratacağından şikâyet konusu olmuştur. $\mathrm{Bu}$ yüzden durumun mahkemede görülerek neden böyle davrandıklarının anlaşılması ve gerekirse cezalandırılmaları istenmişti (KŞS., 21, 80/1).

Bir başka örnekte de 1807 (H. 1222) yılında Mazhar Efendi Vakfı'na bağlı Piskopu'nun Koloş köyünde bulunan çiftliğin içme suyuna Monyad köyü halkının suyu keserek köylerine aktarmaları dolayısıyla vuku bulan şikayet üzerine vakıf suyunun korunması için ferman çıkarılmış, buna rağmen meydana gelen müdahalenin sürmesiyle ikinci bir ferman yazılması gereği ortaya çıkmıştı. Gönderilen ikinci fermanda Lefkoşa kadısı huzurunda görülecek mahkemelerin vakfın haklarının zedelenmeyerek sonuçlandırılması istenilmişti (KŞS., 26, 67/2).

Ayasofya Camii şadırvanına akan içme suyundan, suyun geçtiği Arap Ahmet Paşa mahallesi halkı ve bazı su sahipleri vakfiyede belirtildiği miktarlarda su almaktaydılar. Ancak hem mahalle halkından hem de su sahiplerinden bazıları evlerine vakfiyede yazılı olan hakk-1 mecrâlarına kanaat etmeyip beşer masura daha su istemişler ve hatta bazıları suyu kapatarak on bazıları da yirmi masura suyu kendi hisseleridir diyerek evlerine almışlardı. Bu ise camiye gelen suyun azalmasına yol açmıştı. Meydana gelen şikâyet üzerine verilen emirde hak sahiplerinin yerinde belirlenmesi ve bunun dışında kesinlikle fazla su verilmeyerek vakıf suyunun korunması istenmişti (KȘS., 32, 85/1, H. 1242/M. 1827-1828).

Girne'nin Vasilya köyünde bulunan ve fetihten beri Tûr-1 Sinâ'ya tâbi Aya Praşoki Manastırı'na ait olup Nurlu dağından çıkan Aya Valas adlı vakıf içme suyuna aynı köyden 1777 (1191) senesinde Hacı Ömer, 1815 (1230) ve 1840 (1256) senelerinde yine aynı köyden bazı şahıslar kendi tarlalarında kullanmak üzere müdahalede bulunmuşlardır. Üç ayrı tarihte de Divan-1 Hümayun'dan verilen fermanlarda adı geçen suyun vakıf tarafından fetihten beri kullanageldiği belirtilerek yerinde yapılacak yargılama ile vuku bulan müdahalenin önlenmesi ve suçluların cezalandırılması emredilmişti (KŞS., 38, 188/2).

1855 (Safer 1272) yılında Girne'nin Lapta köyünde bulunan Eski Cami'nin su ihtiyac1 ve halkın bahçelerde ihtiyacı için kullandıkları sularına yine aynı köyden Hacı İbrahim ve Hasan adlı kardeşler kuyunun bulunduğu yere yakın bir alanda kiraladıkları arazide açtıkları kuyular ve kanallarla mevcut cami kuyusundaki suyu gaspederek kendi kuyu bahçelerine aktarmışlardır. Hacı İbrahim ve kardeşi Hasan iddiayı reddetmişlerse de mahkeme tarafından bilirkişilerce yerinde kazılar yaptırılarak yürütülen muhakemede durumun belirtildiği biçimde meydana gelmekte olduğu açık biçimde ortaya çıkmış ve adı geçen kardeşler vakıf suyuna müdahaleden men olunmuşlardır (KŞS., 44, 50/1).

Kıbrıs'ta vakıf sularıyla ilgili ortaya çıkan sorunlar sadece vakıf sularına dışarıdan yapılan müdahaleler değildi. Vakıflar tarafından vakfa ait olmayan sulara yapılan müdahaleler de sorun teşkil edebilmekteydi. Bunlardan birinde Lefkoşalı Münibzade Mehmet Sadık, Baf kapısı yakınında sahip olduğu çiftliğe İncirli adlı yerden gelen sudan faydalanmaktayken 1787-1788 (1202) senesinde Ayasofya vakfı mütevelli kaymakamı Esseyyit Hüseyin Efendi'nin adı geçen 
sudan caminin suyuna almak istemesi sonucu Münibzade Mehmet şikâyetçi olmuştu. Müştekinin Divan-1 Hümayun'a şikâyet dilekçesini sunmasından sonra durum müştekinin iddiası üzere eskiden beri kullanageldiği suyu ise mahallinde yapılacak yargılamayla mütevelli kaymakamının müdahalesinin engelenmesi gerektiği açıklanmıştı (KŞS., 21, 214/1).

Benzer bir örnek de Seyyit Hacı Mehmet'in babasından kalan İpsomolof köyündeki akarsuya Cafer Paşa evkafi mütevelli vekilinin zorla aldığı bir temessükle müdahalesi sonucu yaşanmıştır. Seyyit Hacı Mehmet, mütevelli vekilinin kendisinden zorla aldığı bir temessükle suyu gaspettiğini iddia etmektedir. Seyyit Hacı Mehmet'in Divan-1 Hümayun'a yazdığı ve durumu açıklayan arzuhali üzerine konuyla ilgili olarak Lefkoşa naibine, belirtilen akarsu eğer müştekinin iddia ettiği gibi babasından kalan mülkü ise "bu makûle su nizấ 'nda i tibâr-l kadîme olduğundan" hareketle mahallinde mahkemece görülecek davalarında eskiden beri nasıl yürütülmüşse ona göre hareket edilmesi gerektiği açıklanmıştı (KŞS., 24, 127/1).

Yapılan tahkikat ve muhakemede Cafer Paşa vakfı mütevelliyesi Halil kızı Nimeti Hatun ise vakfa ait olduğunu ileri sürdüğü vakıf arazisi ve sularını Seyyit Elhac Mehmet Efendi b. Elhac Mahmut'un gaspettiğini iddia ederek şikâyetçi olmuştu. Ancak mahkemede görülen davalarında Seyyit Elhac Mehmet Efendi b. Elhac Mahmut'un tasarrufunda bulunan akarsular ve arazilerin 35 yıldır babasından intikal eden mülkü olduğunu kanıtlamasıyla mahkemece Cafer Paşa vakfı mütevelliyesi Halil kızı Nimeti Hatun'un iddiasının geçersiz olduğu anlaşılmıştır (KŞS., 26, 74/2)

\section{Vakıf Su Yollarıyla Ortak Çalışma}

Kıbrıs'ta su kaynakları sınırlı olduğundan ortaya çıkan suları kentlere ve hanelere ulaştırmak eskiden beri büyük bir külfet oluşturmaktaydı. Dolayısıyla yeni ortaya çıkan suları hanelere getirmek için hâlihazırda mevcut su yollarını kullanmak en sık kullanılan yöntemdi. Bu usul Kıbrıs'ta özellikle Lefkoşa Kalesi dışında kazılıp ortaya çıkarılan yeni suları kale içindeki hanelere nakil amacıyla kullanılmaktaydı. Bu bazen vakıf suyunun getirilmesi için şahıs su yolunun kullanımı, bazen de şahısların kendi sularını getirmek için vakıf su yollarını kullanmaları şeklinde görülmekteydi. Ancak en sık görüleni, şahısların vakıf su yollarını kullanma talepleri biçimindeydi. Böylesi durumda şahıslar mütevellinin izni doğrultusunda ve vakıf su yollarını kullanma karşılığında hakk-1 mecrâ (su yolu hakkı) ödemekle yükümlüydü. Şahıslar vakıf su yolunu kullanmak isterlerse hâsıl ettikleri suyun fazlasını vakıflara da bırakırlardı.

$\mathrm{Bu}$ konuya dair ilk örneklerden birinde Mustafa Paşa evkafi dâhilinde bulunan Ömeriye Camii'ne vakfedilen suya Kıbrıslı Mustafa adlı çorbacı kendi gelirlerinden yeniden on adet kuyu kazdırarak ve çıkan suyun yarısını camiye, diğer yarısını da kendi hanesine aktararak su yoluna ortak olmuştur. Ayrıca vakfa her yıl 360 akçe mukataa veren Mustafa Bey su yollarını da kendi gelirlerinden tamir ettirmiştir. (KŞS., 5, 86/2, H. 1088/M. 1677).

Lefkoşa'nın Arap Ahmet Paşa mahallesinden Ramazan Çelebi b. Hüseyin İncirli köyü yakınında açtırmış olduğu kuyunun suyunu Lefkoşa ve Ayasofya evkafı mütevellisinin izniyle vakıf sularına dâhil ederek bir miktarını kendi hanesine almak istemişti. Mahkemeden görevlendirilen bilirkişiler vasıtasıyla Lefkoşa'ya gelen suyun 50 masurasının Ramazan Çelebi hanesine verilmesi kararlaştırılmıştı (KŞS., 9, 53/5, H. 1130/M. 1717-1718).

Ayasofya camisine gelen vakıf suyundan Lefkoşa'nın Karamanzade mahallesinde Esfarzade hanesi olarak bilinen hanede oturanlar 1708 yılından beri bu sudan kale dişında üç adet su kuyusu kazdırma, buradan çıkacak suyun üç masurasını vakfa bırakma ve yıllık üç kuruş hakk-1 mecrâ karşıllğında mütevelli izniyle vakıf su yolunu kullanmaktaydılar. Ancak zamanla kuyular kuruduğundan 1796 senesinde adı geçen hanede oturan Sergiz adlı zimmi bu su yolunu kullanamaz hale gelmişti. Sergizin aynı yerde altı yeni kuyu kazdırarak buradan çıkan on masura suyun yedisini vakfa bırakma ve senede üç kuruş hak-1 mecrâ karş1lığında geriye kalan üç masura suyun kendi hanesine gidebilmesi için vakıf su yolunu kullanmasına izin verilmiş̧i (KŞS., 21, 


\section{1/2, H. 1210/M. 1795-1796).}

Kıbrıs Muhassılı Ali Ruhi Efendi Haremeyn Evkafi'na bağlı olarak Ayasofya ve Ömeriye camilerine gelen Lefkoşa Kalesi dışındaki su kaynakları çevresinde kazdırdığı 35 kuyudan toplam 16 lüle (26 mm çapındaki bir borudan akan suyun debisine bir lüle denir (Çeçen, 1999, 59) su elde edilmiştir. Bu suyun Abdi Çavuş mahallesinde yaptırdığı camiye ulaştırılması için 16 lüle suyun 14 lülesini Haremeyn Evkafı'na bağışlayarak kalan 2 lülesini yeni yaptırdığı camiye ve Abdi Çavuş mahallesindeki evine götürmek için İbrahim Paşa mahallesindeki maksemden alması Harameyn Evkafı'nın Kıbrıs'taki kaymakamı tarafından kabul edilmişti (KŞS., 33, 29/1, H. 1243/M. 1827-1828; KVGMA., Kara Kaplı Vakfiye Defteri, 39/2).

Lefkoşa'nın Cami-i Cedit mahallesinden Topçu Yüzbaşı Mehmet Ağa b. Davut'un İncirli köyünde açtırdığı üç kuyudan çıkan suyun bir masurasını evine getirebilmek için kalan suyu Cami-i Cedit Vakfı'na bırakma şartıyla vakıf su yolunu kullanmasına izin verilmişti (KŞS., 39, 37/2, H. 1258/M. 1842).

1867 (1283) y1lında Himmet Efendizâde Naim Efendi kendi hanesine su getirebilmek için Laleli camii vakıf suyu yolunu kullanmak istediğinde vakıf mütevellisi tarafından kendisine izin verilmişti (KVGMA, Küçük Vakfiye Defteri, 40/7).

\section{Kıbrıs Su Vakıflarının Benzerleriyle Karşılaştırııması}

Kıbrıs su vakıflarını ülkenin diğer bölgeleriyle karşılaştırmak gerektiğinde öncelikle benzerlikler üzerinde durmak icab eder. Zira vakıf, bir hayır ve hasenat uygulaması olduğu kadar hukukî bir akittir. Dolayısıyla Kıbrıs' ta kurulmuş bulunan su vakıflarını, hukukî boyutta, devletin diğer bölgelerindeki örneklerinden ayırmak mümkün değildir. Bu anlamda su vakfının kuruluşu, vakıfta görev yapacak görevlilere ödenecek ücretlerin saptanması, vakıflara ait suların hangi şartlarda kiraya verileceği, hangi şartlarda kullanılacağ 1 , vakıfların nizamnameleri hüviyetindeki vakfiye kayıtlarında hükme bağlanmıştır (Şensoy, 2006, 117-120). Yine hukukî boyutta olmak üzere Kıbrıs su vakıflarının diğer kurumlar veya şahıslarla yaşadıkları sorunların çözümünde "kadimden beri", yani kişi veya vakıfların önceden kazanılmış haklarının korunması şeklinde yol izlenmekteydi ("bu makûle su nizấ 'ında i'tibâr-ı kadîme olduğundan", KŞS., 24, 127/1; Şensoy, 2006, 121).

Kıbrıs su vakıflarının diğer bölgelerdeki vakıf sularla bir benzerliği de keşiflerle ilgilidir. Sularla ilgili keşifler, yeni bir kuyu kazılacağında (KŞS., 28, 149/2), bozulan su aksamının tamirinde (KȘS., 5, 45/2), su miktarının belirlenmesinde (KȘS., 9, 53/1), vakıf suyuna yapılacak katmalarda (KŞS., 33, 29/1), vakıf sularına yapılan müdahalelerde (KŞS., 44, 50/1), su yolunun nereden alınacağı (KŞS., 5, 86/2) gibi gerekçelerle yapılmıştır. Bu uygulamalar Kıbrıs'ta olduğu gibi ülkenin geneli için geçerli bir husustu. Keşifler Kıbrıs'ta su vakıflarında zaman zaman bilirkişi (ehl-i vukûf) olarak görevlendirilen suyolcular vasıtasıyla yürütülmüştür. Kıbrıs su vakıflarında belirtildiği üzere kullanılabilecek diğer görevliler istihdam edilmemiştir (Çelik, 2000, 27-33; İlhan, 2008, 47-48).

Kıbrıs vakıf sularının diğer şehirlerdeki örnekleriyle bir başka benzerliği de vakıf sularına yapılan katmalarla ilgilidir. Hayır sahipleri tarafından vakıf sularının devamı ve gelişimi için İstanbul'da ve diğer bölgelerde, Kıbrıs'taki örneklerle açıklanan sistem uygulanmaktaydı (Çelik, 2006, 267). Kıbrıs su vakıfları su yollarına belirli ücretler ve katkılar şartıyla yapılan katmalarda uygulanan "hakk-ı mecrâ" usûlü İmparatorluğun diğer bölgelerinde uygulanan usûllerle büyük benzerlikler taşımaktadır (KŞS., 21, 321/2, H. 1210/M. 1795-1796; Tabakoğlu, 2006, 159; Karataş, 2008, 386). Su vakıflarına yapılacak katma miktarının belirlenmesinde, yani suyun vezninde diğer şehirlerin su vakıflarında olduğu gibi Kıbrıs’ta da çoğunlukla bilirkişi statüsünde çalışan suyolcular görev yapmaktaydı (KŞS., 9, 53/5; Zeybekoğlu, Çakır. \& Özenç, 2007, 31). Yine bu anlamda suyun miktarının belirlenmesinde kullanılan ölçü birimleri de (nim çuvaldız, 
çuvaldız, masura, kamış, lüle) bütün ülkede kullanılan su ölçü birimleriydi (Çeçen, 1999, 55 vd.).

Kıbrıs vakıf sularına katma yapıldığı gibi belirli sürelerle kiralanması da mümkündü. Ancak bu vakıf mütevellisinin izni doğrultusunda gerçekleşebilirdi. Mütevelli izni olmadan yapılacak kiralamalar kanuna aykırı kabul edilmiştir (KVGMA., Atik Emirname Defteri, 45/2). Vakıf sularından kiralama sadece Kıbrıs'ta değil neredeyse fazla suyu bulunan bütün vakıflarda görülen bir uygulamadır. Yine bu uygulamada verilecek suyun miktarı suyolcular tarafından belirlenmekteydi (Çelik, 2006, 276-282).

Kıbrıs su vakıflarının işleyişinde karşılaşılan bir başka benzerlik de vakıfların su aksamlariyla ilgilidir. Kıbrıs su vakıflarında su tesisi olarak kuyular, bendler, havuzlar, kemerler, sskaralar, sedler, maksemler, savaklar diğer bölgelerdeki su tesisatlarında görülen sistemlerle benzerlik taşımaktadır (Tabakoğlu, 2006, 178; Zeybekoğlu vd., 2007, 30; Karataş, 2008, 386 vd).

$\mathrm{Su}$ vakıfları belirli grupların, özellikle de esnaf teşkilatının faydalanması amacıyla da oluşturulabiliyordu (Şensoy, 2006, 115; Çelik, 2006, 288). Ancak Kıbrıs'ta bir vakıf suyunun bu şekilde tahsisine rastlanılmamıştır.

\section{Sonuç}

Osmanlı yönetimi boyunca Kıbrıs'ta en büyük su vakıfları adaya atanan beylerbeyi/mütesellim/ muhassıl bulunan valilerce kurulmuştur. Arap Ahmet Paşa, Cafer Paşa, Ebubekir Paşa, Silahtar Mustafa Paşa gibi valiler, ada halkına sadece adaletli bir idarede sunmaya çalışmamışlar, halkın en önemli ihtiyacını kendi gelirlerinden kurdukları su vakıflarıyla karşılamaya gayret etmişlerdir. Ayrıca ada halkından ekonomik açıdan varlıklı olanlar da mevcut vakıfların devamını sağlamak üzere su vakıflarına bağışlar yapmışlardır. Bazıları da vakıf su yollarını kullanmak üzere yardımlarda bulunmuşlardır.

Kıbrıs'ta su vakıflarıyla şahıslar arasında yaşanan sorunlar ise çoğu zaman vakıfların lehine neticelendiği ortaya çıkarılan bir diğer sonuçtur. Bu ise devletin su vakıflarının zarar görmesini engelleme ve devamlarını sağlama politikasının bir göstergesidir.

Kıbrıs su vakıfları ile ilgili ortaya çıkarılan bir diğer sonuç ise, ülkenin diğer bölgelerindeki örnekleriyle hukukî altyapı, kuruluş, işleyiş, yaşanan sorunların çözümü bakımlarından büyük benzerlikler taşıdığı olmuştur. 
Tablo 3. Kibrıs Su Vakıfları

\begin{tabular}{|c|c|c|c|c|}
\hline $\begin{array}{l}\text { Su Vakfi Kuran- } \\
\text { lar veya Vakfa } \\
\text { Yardım Edenler }\end{array}$ & Vakfin veya Yardımın Değeri & $\begin{array}{c}\text { Vakfın Bulunduğu } \\
\text { Bölge }\end{array}$ & Tarihi & Kaynak \\
\hline 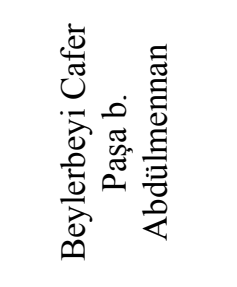 & $\begin{array}{l}\text { Yermasoya ve Putakya köylerinde; } \\
\text { 1. Akarsuyuyla birlikte } 1000 \text { dönüm tarla, } \\
\text { 2. Akarsuyuyla birlikte hudutları belirli mezra ve araziler, } \\
\text { 3. } 100 \text { dönüm tarla, zeytin ağaçları, } \\
\text { 4. Sularıyla birlikte } 16 \mathrm{ev,} \\
\text { 5. Akarsuyuyla birlikte bahçe }\end{array}$ & $\begin{array}{l}\text { Mağusa'ya götürdüğü } \\
\text { akarsuyun su yolu } \\
\text { masrafina }\end{array}$ & $\begin{array}{l}\text { H. 1001/M. 1599- } \\
1600 \\
\text { H. 1016/M. 1607- } \\
1608\end{array}$ & $\begin{array}{l}\text { BOA., 2000, 203-205; } \\
\text { Altan, 1986, 471. }\end{array}$ \\
\hline 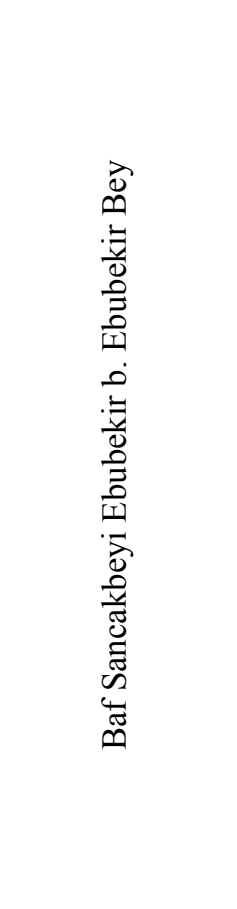 & $\begin{array}{l}\text { 1. Ktima kasabasında } 1 \text { hamam, } 1 \text { kahvehane, } \\
\text { 2. Cami-i Şerif Mahallesi'nde } 1 \text { bahçe, } 2 \text { 'şer katlı } 2 \text { ev, } \\
\text { 3. Pazarortası mevkiinde } 1 \text { kilise (mahzen olabilecek) ve muhtelif dükkanlar, } \\
\text { 4. Kuruka, Hulu, Limona, Kato Panaya, İpşat,, Koloni ve Malunda köylerinde } \\
\text { fethinden sonra devletten satın aldığı su basar ve kıraç tarlalar, } \\
\text { 5. Finike, Pada, Fayda Platanissa, İksilihorya, Lazar ve Nada köylerinde harnub, pelit, } \\
\text { zeytin ağaçları ile meyveli ve meyvesiz ağaçlar, } \\
\text { 6. Ktima kasabasında devletten satın alınan Despotye denilen tarla, } \\
\text { 7. Şironya köyünde Vasiliko adıyla bilinen sudan köye gelen su, } \\
\text { 8. Akarsuyuyla birlikte Aya Frende adıyla bilinen tarla, } \\
\text { 9. Falya mevkiinde Kalamiri adıyla bilinen akarsuyu ile birlikte bir kıta tarla, } \\
\text { 10. Aşelya köyünde } 1 \text { su değirmeni ve bahçe, } \\
\text { 11. Platanissa köyünde } 1 \text { su değirmeni, } \\
\text { 12. Sendi köyünde } 1 \text { su değirmeni,Malunda köyünde } 2 \text { su değirmeni, su basar ve kıraç tarlalar, } \\
\text { 13. Finike köyünde } 1 \text { su değirmeni, } 1 \text { yağ değirmeni, } \\
\text { 14. Celocedra köyünde } 1 \text { su değirmeni, } \\
\text { 15. Petavropo köyünde Şildon adıyla bilinen } 1 \text { su değirmeni, } \\
\text { 16. Tuzla Kokkina köyünde akarsuyuyla birlikte } 1 \text { kıta arazi, } \\
\text { 17. İşa köyünde akarsuyuyla birlikte } 1 \text { kıta arazi, } \\
\text { 18. Piryan köyünde akarsuyuyla birlikte } 1 \text { kıta arazi. }\end{array}$ & Baf Kazası & $\begin{array}{l}\text { H. 1001/M. 1592- } \\
1593\end{array}$ & $\begin{array}{l}\text { Altan, 2003, 586; } \\
\text { BOA., 2000, 201-202. }\end{array}$ \\
\hline
\end{tabular}




\begin{tabular}{|c|c|c|c|c|}
\hline 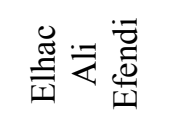 & $\begin{array}{l}\text { 1. Bir hamam } \\
\text { 2. Maratasa deresinde olan hakk1 }\end{array}$ & Omorfo, Lefkoşa & H. 1102/M. 1690 & $\begin{array}{c}\text { Y1ldız, 1996, 98; } \\
\text { Gazioğlu, 2000, 251-252 }\end{array}$ \\
\hline 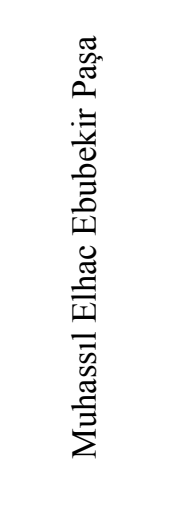 & $\begin{array}{l}\text { 1. Sarayönü Camii yanında } 23 \text { dükkan, } \\
\text { 2. Tuzla'nın Arpere köyünde İstavros bahçesi yanından ve yine aynı bahçe önünden } \\
\text { akan derenin üstünden, Fransız tercümanı bâğçesi üstünden ve yeniden açılan } \\
\text { kuyulardan çıkan ve Tuzla merkez ve İskeleye gelen su, } \\
\text { 3. Aynı suyun mecrâsı altında Kolonbo denilen mahalde ağaçları, bağı ve bahçesiyle } \\
\text { birlikte } 37 \text { dönüm arazi ve dahilindeki buğday değirmeni, } \\
\text { 4. Aynı suyun yolu altında Tuzla kasabasına yakın Aya Yorgi Manastırı yakınındaki } \\
\text { köprünün karşısında bulunan buğday değirmeni, } \\
\text { 5. Muhassıl sarayına bitişik vakfedilen dükkanların ardında inşa edilen büyük bir köşk, } \\
\text { 6. } 1.000 \text { zirâ avlu (duvar ve müştemilâtıyla), } \\
\text { 7. Tuzla'nın Arpere köyünde vakfedilen bahçeye bitişik inşa edilen } 12 \text { oda ve bir } \\
\text { ahırdan oluşan çiftliği (bütün müştemilatıla). }\end{array}$ & Tuzla & $\begin{array}{l}\text { H. } 12 \text { Rebiulevvel } \\
\text { 1161/M. } 12 \text { Mart } \\
1748\end{array}$ & $\begin{array}{l}\text { KŞS., 17, 97/1; KŞS., } \\
17,100 / 2\end{array}$ \\
\hline 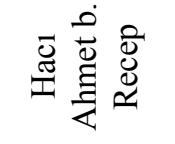 & 1. Unpazarı'nda bulunan bakkâl dükkânın icâre-i sahiha ile kira bedeli & Lefkoşa & $\begin{array}{l}\text { H. } 14 \text { Şevval } 1186 / \\
\text { M. } 8 \text { Ocak } 1773\end{array}$ & $\begin{array}{l}\text { KVİA., Kara Kaplı } \\
\text { Vakfiye Defteri, 122/1 }\end{array}$ \\
\hline 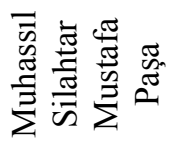 & - & Lefkoşa & $1796-1798$ & $\begin{array}{l}\text { KŞS., 28, 149/2; } \\
\text { Çevikel, 2000, } 338 .\end{array}$ \\
\hline 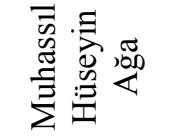 & $\begin{array}{l}\text { 1. İncirli köyünde } 113 \text { su kuyusu, } \\
\text { 2. Lefkoşa'ya akan sudan } 10 \text { masura su hakk1, } \\
\text { 3. } 500 \text { kuruş }\end{array}$ & Lefkoşa & $\begin{array}{l}\text { H. 1216/M. 1801/ } \\
1802\end{array}$ & \\
\hline
\end{tabular}




\begin{tabular}{|c|c|c|c|c|}
\hline 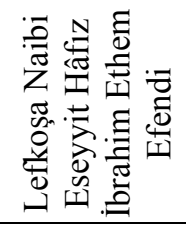 & Su kuyusundan alınacak fazla su Ayasofya camiine & Lefkoşa & H. 1220/ M. 1806 & KŞS., 26, 12/3 \\
\hline 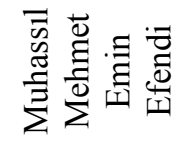 & 1.500 kuruş & $\begin{array}{c}\text { Lefkoşa, Tuzla yolu, } \\
\text { Girne }\end{array}$ & H. 1232/M. 1817 & $\begin{array}{c}\text { KŞS., 29, 132/1; } \\
\text { KVGMA, Kara Kaplı } \\
\text { Vakfiye Defteri, } 216\end{array}$ \\
\hline 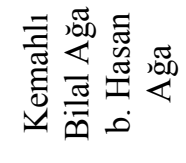 & 1.800 kuruş & Leymosun & H. 1233/M. 1818 & KŞS., 29, 209/1 \\
\hline 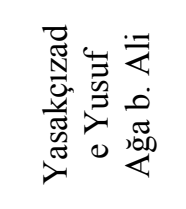 & 16.516 kuruş & $\begin{array}{l}\text { Silahtar suyunun su } \\
\text { yolları ile Eğlence } \\
\text { köyündeki çeşme ve } \\
\text { Tuzla yolundaki } \\
\text { çeşmenin tamirlerine }\end{array}$ & $\begin{array}{c}\text { H. } 19 \text { Muharrem } \\
\text { 1283/M. } 3 \text { Haziran } \\
1866\end{array}$ & KŞS., 47, 148/1 \\
\hline
\end{tabular}




\section{KAYNAKÇA}

\section{Araştırma Eserleri}

Akgündüz, A. (1988). İslâm Hukukunda ve Osmanlı Tatbikatında Vaklf Müessesesi. Ankara: TTK. Yayinı.

Altan, M. H. (1986). Belgelerle Kıbrıs Türk Vakıflar Tarihi (1571-1974), I. Lefkoşa: Kıbrıs Vakıflar İdaresi Yayını.

Altan, M. H. (2001). Kıbrıs'ta Türk Malları, III. Lefkoşa: Karataş Yayınevi.

Altan, M. H. (2003). Klbrls'ta Türk Mallarl, II. Lefkoşa: Yeni Avrasya Yayınları.

Ateş, İ. (1987). Kanuni Sultan Süleyman'ın Su Vakfiyesi. Ankara: Kültür ve Turizm Bakanlığı Yayını.

Bağışkan, T. (2005). Kıbrıs'ta Osmanl-Türk Eserleri. Lefkoşa: Mavi Basın Yayın.

Berki, A. H. (1962). "Vakıf Kuran İlk Osmanlı Padişahı". Vakıflar Dergisi, 5, 127-128. Ankara: Vakıflar Genel Müdürlüğü Yayını.

BOA., (2010). Osmanl İdaresinde Kıbrıs, Ankara: Devlet Arşivleri Genel Müdürlüğü Başbakanlık Osmanlı Arşivi Daire Başkanlığı.

Cobham, C. D. (1908). Excerpta Cypria: Materials for a History of Cyprus. Cambridge: Cambridge University Pres".

Çeçen, K. (1999). Osmanlı Suyollarında Künkler, Debi Ölçme Tertibatı ve Su Terazileri”. Osmanlı İmparatorluğu'nun Doruğu 16. YY. Teknolojisi, 55-70. İstanbul: İstanbul Büyükşehir Belediyesi Yayını.

Çelik, G. (2000). İstanbul Su Külliyatı, Vakıf Su Tahlilleri: Su Hukuku ve Teşkilâtı. İstanbul: İSKİ Yayınları.

Çelik, G. (2006). “İstanbul Kaynak Sularında Teşkilat ve İşleyiş”. Suyu Arayan İstanbul. 267-312. İstanbul: İSKİ Yayınları.

Çevikel, N. (2000). Kıbrıs Eyaleti, Yönetim, Kilise, Ayan ve Halk (1750-1800). Gazimağusa: Doğu Akdeniz Üniversitesi Basımevi.

Çoruh, H. (2008). II. Mahmud Döneminde Kıbrıs'ın İdari, İktisadi ve İçtimai Yapısı (1808-1839). Yayımlanmamış Doktora Tezi. Marmara Üniversitesi, İstanbul.

Demiryürek, M. (2011). "Kıbrıs Şer'iyye Sicillerine Göre XIX. Yüzyılın İlk Yarısında Kıbrıs’ta Kurulan Para Vakıfları (Vakf-1 Nükud)". Turkish Studies, 6/1, 941-960.

Dinç, G. (2010). Osmanlı Yönetiminde Kıbrıs (1800-1839). Yayımlanmamış Doktora Tezi. Akdeniz Üniversitesi, Antalya.

Dündar, R. (1998). Kıbrıs Beylerbeyliği (1570-1670). Yayımlanmamış Doktora Tezi. İnönü Üniversitesi, Malatya.

Erdoğru, M. A. (2008). “Osmanlı Kıbrısı'nda Su Tedariki (1570-1640)”. Klbris'ta Osmanlılar, 250-265. Lefkoşa-Kıbrıs: Galeri Kültür Yayını.

Erdoğru, M. A. (2009). “Kıbrıs'ta İlk Osmanlı Evkafı: Sultan II. Selim'in Lefkoşa Sur İçindeki Selimiye Camii ve Selimiye Medresesi’nin Mali Kaynakları”. Kıbrıs'ta Osmanlılar II, 58-64. Lefkoşa-Kıbrıs: Galeri Kültür Yayını.

Erdönmez, C. (2004). Şer 'iyye Sicillerine Göre Kıbrıs'ta Toplum Yapısı (1839-1856). Yayımlanmamış Doktora Tezi. Süleyman Demirel Üniversitesi, Isparta.

Gazioğlu, A.C. (2000). Kıbrıs'ta Türkler (1570-1878), 308 yıllık Türk Dönemine Yeni Bir Bakıļ, Lefkoşa: Kıbrıs Araştırma ve Yayın Merkezi (CYREP).

Güneri, H. (1971). "Vakıf Sular ve Su Vakıfları". Vakıflar Dergisi, IX, 67-79. Vakıflar Genel Müdürlüğü Yayınları.

Gürkan, H. M. (2000). Tarih İçinde Kıbrıs. Lefkoşa: Galeri Kültür Yayını.

Halil, S. (1967), “Osmanlı İdaresinde Kıbrıs'ın Illk Yllı Bütçesi”. Belgeler, S. IV/7-8, Ankara: TTK. Yayını, 1-33.

Hill, G. (1952a). A History of Cyprus, vol. I. Cambridge: Cambridge University Press.

Hill, G. (1952b). A History of Cyprus, vol. IV. Cambridge: Cambridge University Press. 
İlhan, (2008). "Osmanlı Su Yollarının Sevk ve İdaresi". Ankara Üniversitesi Dil ve Tarih-Coğrafya Fakültesi Tarih Bölümü Tarih Araşttrmaları Dergisi, 27/44, 41-66.

Jennings, R. (1993).Christians and Muslim in Ottoman Cyprus and the Mediterranean World (15711640). New York: New York Universty Press.

Kara, A.; Çelik, C. (2011). "Kıbrıs'ta Vakıf Denetim Sorunu”. History Studies, 3/3, 161-175.

Karataş, (2008). "Bursa Suları ve Su Vakıfları". Uludağ Üniversitesi Illahiyat Fakültesi Dergisi, 17/2, 379-417. Bursa.

Kazıcı, Z. (1985). İslâmî ve Sosyal Açıdan Vakıflar. İstanbul: Marifet Yayınları.

Köprülü, F. (1942). "Vakıf Müessesesinin Hukukî ve Mâhiyeti ve Tarihî Tekâmülü”. Vakıflar Dergisi, 2, 1-13. Ankara: Vakıflar Genel Müdürlüğü Yayını.

Luke, H. (1989). Cyprus Under The Turks (1571-1878). London: C. Hurst, \& Company Press.

Martal, A. (1989). "XVI. Yüzyılda Osmanlı İmparatorluğunda Su Yolculuk". Belleten, LII, 205, 15851654. Ankara: TTK.

Ömer Hilmi Efendi. (2003). Ahkâmü'l-Evkâf. Lefkoşa: Kıbrıs Vakıflar İdaresi Yayını.

Özçelik, S. (2003). "Tanzimat Öncesinde Girne Kazası (Temettüat Defterlerine Göre)". A.Ü.D.T.C.F. Tarih Araştırmaları Dergisi, XXII, 34, 35-81. Ankara: Ankara Üniversitesi Yayını.

Özkul, A. E. (2005). Kıbrıs'ın Sosyo-Ekonomik Tarihi (1726-1750). İstanbul: İletişm Yayınları.

Özoran, B. R. (1982). "Kıbrıs Adasında Bekir Paşa Vakfı”. Vakıflar Dergisi. 16, 27-29. Ankara: Vakıflar Genel Müdürlüğü Yayını.

Öztürk, N. (1983). Menşei ve Tarihi Gelişimi Açısından Vakıflar. Ankara: Vakıflar Genel Müdürlüğü Yayin1.

Pakalın, M. Z. (1990). Osmanlı Tarih Deyimleri ve Terimleri Sözlüğü, III. İstanbul: Milli Eğitim Basımevi.

Purcell, H. D. (1968). Cyprus. New York: Praeger Press.

Soyel, N. T. (2009). Kuzey Kıbrıs'taki Tarihi Su Değirmenleri ve Kırsal Peyzajın Parçası Olarak Korunmaları İçin Öneriler. (Yayımlanmamış Doktora Tezi), İstanbul: İstanbul Teknik Üniversitesi.

Soyel, N. T., \& Ahunbay Z. (2011). "Kuzey Kıbrıs'taki Tarihi Su Değirmenlerinin Koruma ve Yeniden Kullanım Önerileri”. ITÜ Mimarlık, Planlama, Tasarım Dergisi, 10/1, 105-115.

Şensoy, F. (2006). “İstanbul'un Tarihi Vakıf Suları ve Kırkçeşme”. Suyu Arayan İstanbul, 73-146. İstanbul: İSKİ Yayınları.

Tabakoğlu, A. (2006). "Kırkçeşme Suları". Suyu Arayan İstanbul, 147-263. İstanbul: İSKİ Yayınları.

Tosun, S. (2003). Alâiyeli Bekir Paşa Vakıfları. (Yayımlanmamış Yüksek Lisans Tezi), Sivas: Cumhuriyet Üniversitesi.

Uçar, F. (2008). Osmanlı Döneminde Bolu'da Paşa Vakıfları. Bolu: Abant İzzet Baysal Üniversitesi Bolu Halk Kültürü Araştırma ve Uygulama Merkezi Yayınları.

Wright, G. R. H. (1992). Ancient Building in Cyprus. Leiden: Brill.

Yediyıldı, B. (1986). "Vakıf". İslâm Ansiklopedisi., 13, 153-172. İstanbul: MEB.

Yediyıldız, B. (1999) “Osmanlılar Döneminde Türk Vakıfları ya da Türk Hayrat Sistemi”. Osmanlılar, 5, Ankara: Yeni Türkiye Yayını.

Yediyıldız, B. (2003). XVIII. Yüzyılda Türkiye'de Vakıf Müessesesi. Ankara: TTK Yayını.

Yıldız, N. (1996). "Aqueducts in Cyprus". Journal for Cypriot Studies, 2/2. Gazimağusa: Eastern Mediterranean University Press.

Zeybekoğlu, D., Çakır, H. K, \& Özenç, A. (2007). "Edirne'deki Su Terazilerinin Analizi”. Trakya Üniversitesi Sosyal Bilimler Dergisi. 8 (1), 29-33.

\section{Arşiv Belgeleri}

Başbakanlık Osmanlı Arşivi Belgeleri (BOA.)

BOA., A.AMD., 85/76.

BOA., A.DVN.MHM.d, 19. 
BOA., C.EV., 454/22988.

BOA., MVL., 782/77.

BOA., MVL., 797/13.

BOA., TŞR.KB.UM., 236/56 (Kıbrıs Mutasarrıflığı Kataloğu, Cezair-i Bahr-i Sefid ve Diğer İdari Merkezlerle Yazışmalar).

Kıbrıs Şer'iyye Sicilleri (KŞS.)

KŞS., Nr. 2, 5, 9, 14, 17, 19, 21, 24, 28, 29, 32, 33, 36, 38, 41, 42, 44, 45, 47

Kıbrıs Vakıflar Genel Müdürlüğü Arşivi (KVGMA.)

Atik Emirname Defteri

Kara Kaplı Vakfiye Defteri

Küçük Vakfiye Defteri 
